\title{
Embedded Sensor Development in Metallic Structures for the \\ Transformational Challenge Reactor
}

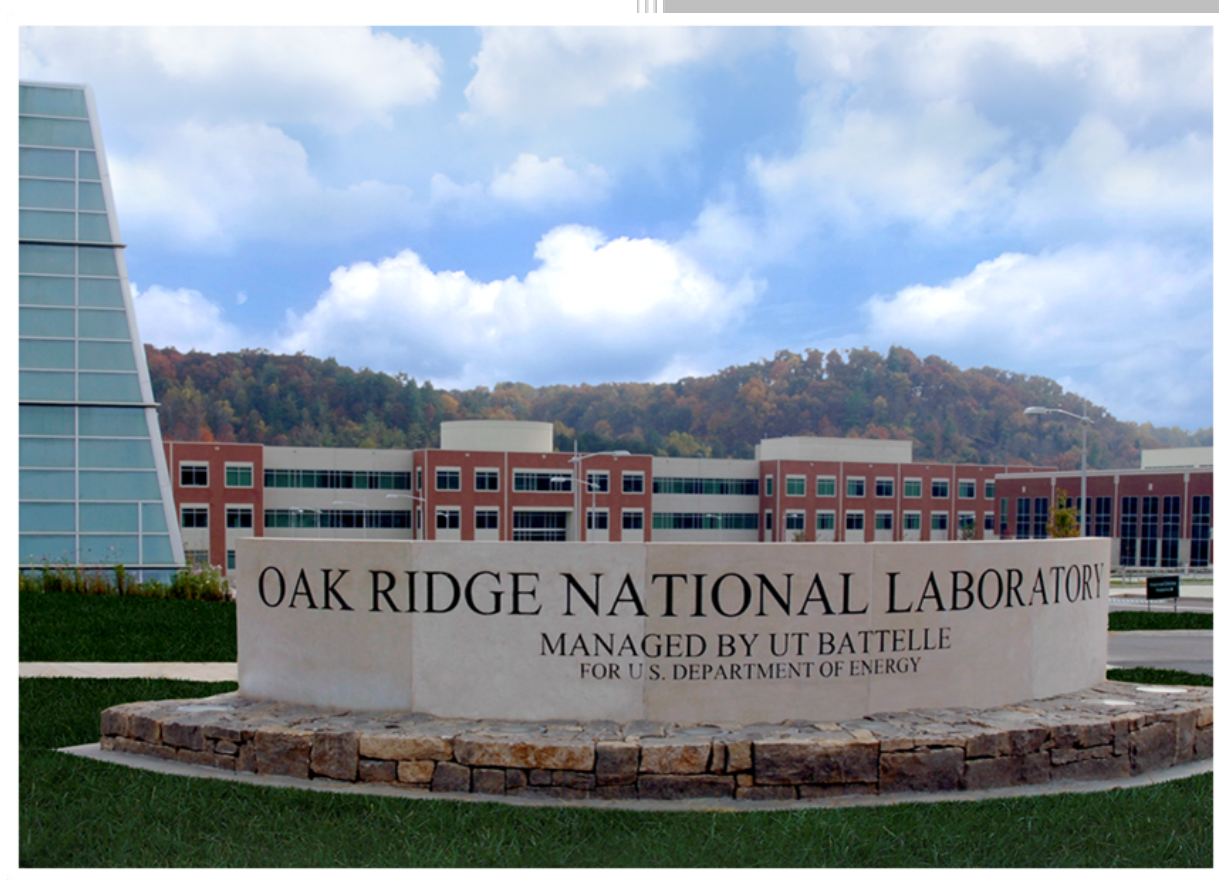

Yarom Polsky

Paul Groth

Bruce Warmack

Alex Melin

Roger Kisner

September 27, 2019 


\title{
DOCUMENT AVAILABILITY
}

Reports produced after January 1, 1996, are generally available free via US Department of Energy (DOE) SciTech Connect.

Website http://www.osti.gov/scitech/

Reports produced before January 1, 1996, may be purchased by members of the public from the following source:

\author{
National Technical Information Service \\ 5285 Port Royal Road \\ Springfield, VA 22161 \\ Telephone 703-605-6000 (1-800-553-6847) \\ TDD 703-487-4639 \\ Fax 703-605-6900 \\ E-mail info@ntis.gov \\ Website http://classic.ntis.gov/
}

Reports are available to DOE employees, DOE contractors, Energy Technology Data Exchange representatives, and International Nuclear Information System representatives from the following source:

Office of Scientific and Technical Information

PO Box 62

Oak Ridge, TN 37831

Telephone 865-576-8401

Fax 865-576-5728

E-mail reports@osti.gov

Website http://www.osti.gov/contact.html

This report was prepared as an account of work sponsored by an agency of the United States Government. Neither the United States Government nor any agency thereof, nor any of their employees, makes any warranty, express or implied, or assumes any legal liability or responsibility for the accuracy, completeness, or usefulness of any information, apparatus, product, or process disclosed, or represents that its use would not infringe privately owned rights. Reference herein to any specific commercial product, process, or service by trade name, trademark, manufacturer, or otherwise, does not necessarily constitute or imply its endorsement, recommendation, or favoring by the United States Government or any agency thereof. The views and opinions of authors expressed herein do not necessarily state or reflect those of the United States Government or any agency thereof. 
ORNL/TM-2019/1354

Electrical and Electronic Systems Research Division

Embedded Sensor Development in Metallic Structures for the Transformational Challenge Reactor

\author{
Yarom Polsky \\ Paul Groth \\ Bruce Warmack \\ Alex Melin \\ Roger Kisner
}

Date Published: September 27, 2019

Milestone \#: M3CT-19OR06090139

Prepared by OAK RIDGE NATIONAL LABORATORY

Oak Ridge, TN 37831-6283

managed by

UT-BATTELLE, LLC

for the

US DEPARTMENT OF ENERGY

under contract DE-AC05-00OR22725 



\section{CONTENTS}

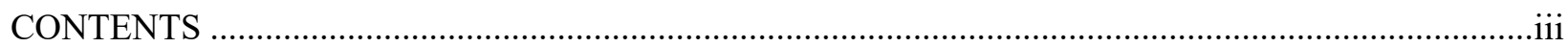

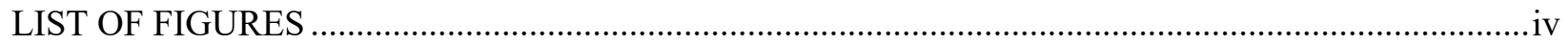

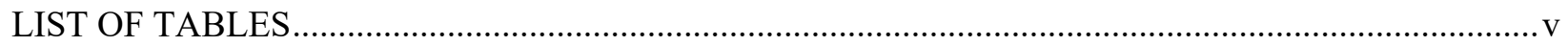

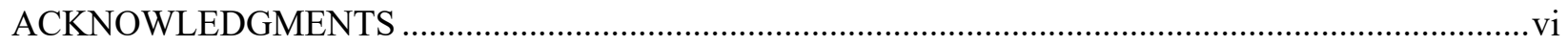

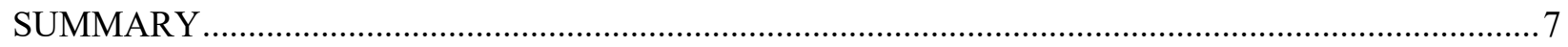

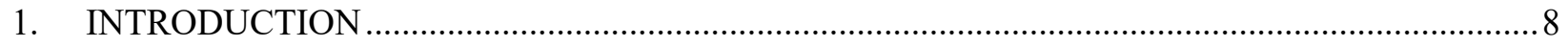

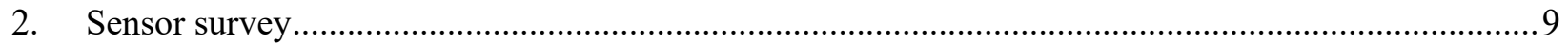

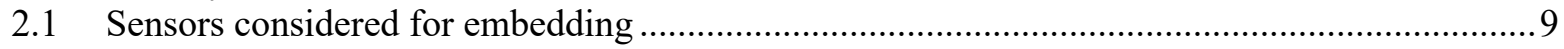

3. Conceptual framework for evaluating embedment feasibility using adDitive manufacturing............ 17

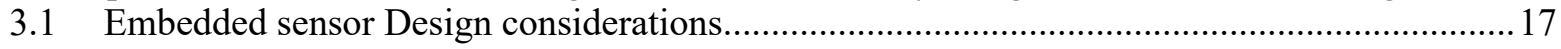

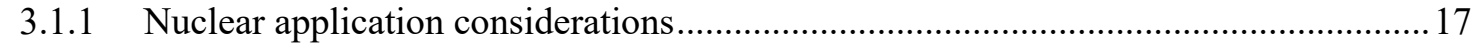

3.1.2 Additive manufacturing considerations............................................................. 18

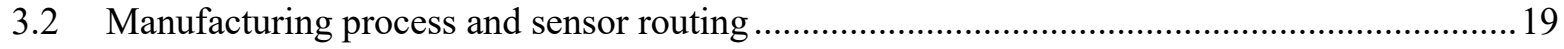

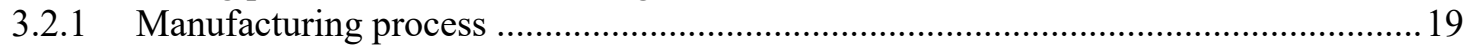

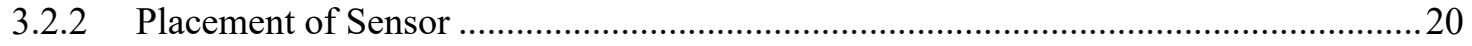

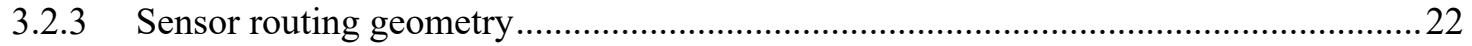

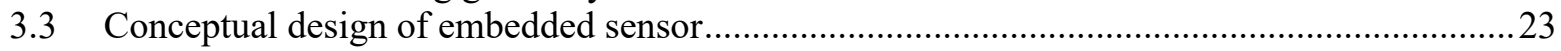

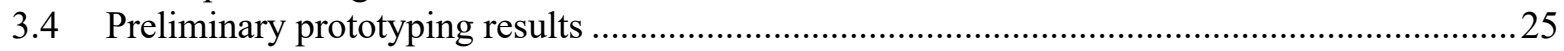

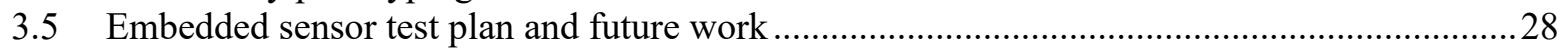

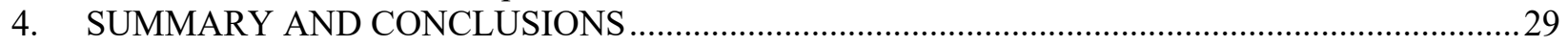




\section{LIST OF FIGURES}

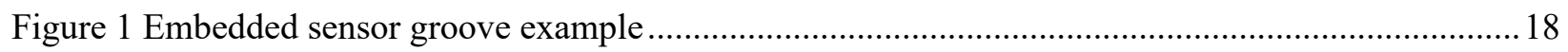

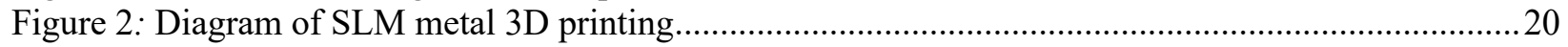

Figure 3: Options for stop-and-go embedment: 1. Half and Half; 2. U-Shaped Groove; 3. Equal

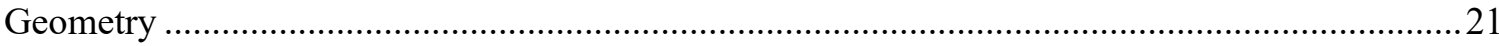

Figure 4: Cross-section of a thermocouple

Figure 5 Simplified powder bed additive manufacturing setup...........................................................22

Figure 6 Representation of simplest three-dimensional routing path with one plane of twodimensional complexity....

Figure 7: Conceptual design combining conventionally machined part and AM characterization

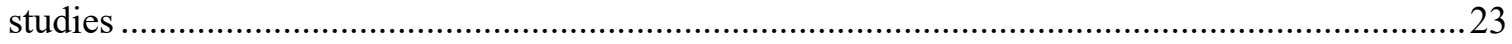

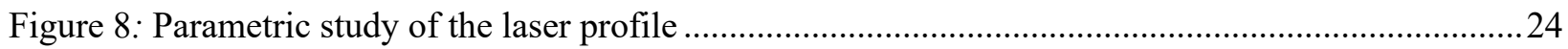

Figure 9: Printed parts for groove dimensional analysis and surface roughness study ............................24

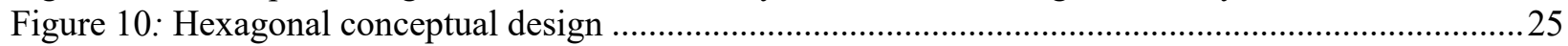

Figure 11: Conventionally machined plates. From left to right - EDM, CNC milling, and CNC milling with embedded thermocouple. Far right shows this thermocouple reading

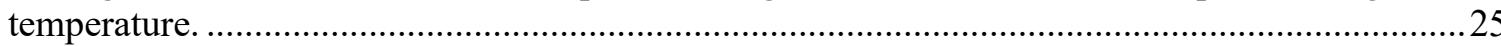

Figure 12: Preliminary printed part with groove depth and width variation ranging from $2.25 \mathrm{~mm}$

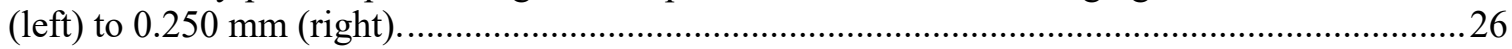

Figure 13: Left shows 8 highlighted lines that were examined by a Keyence optical profilometer.

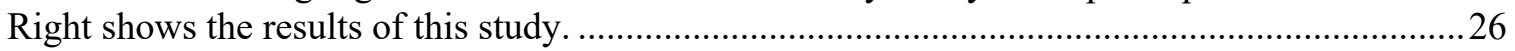

Figure 14: An example of a plasma weld between 316 SS hypodermic tubing and a printed part. Weld settings are: $2 \mathrm{~W} \cdot \mathrm{s}$ power, $2.5 \mathrm{~ms}$ pulse width, sloped waveform, standard tip mode,

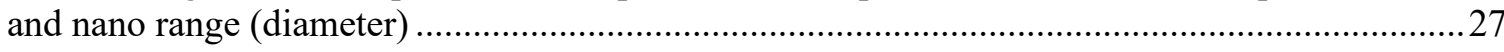

Figure 15: Failed build of machined plate with embedded tubing fabricated using the SLM printer.........27

Figure 16: Honeycomb part before embedding, after embedding and completed build ...........................22 


\section{LIST OF TABLES}

Table 1 Listing of commercial temperature sensors for TCR application................................................. 10

Table 2 Brief description of common neutron detectors used in nuclear reactors. ................................. 11

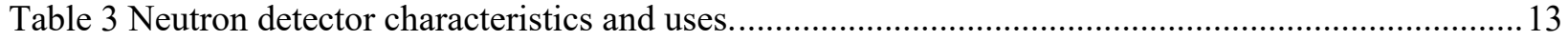

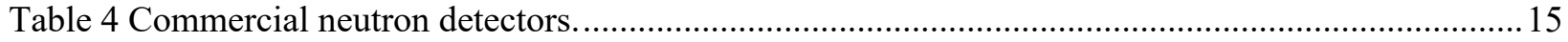




\section{ACKNOWLEDGMENTS}

This research was sponsored by the Transformational Challenge Reactor (TCR) Program of the US Department of Energy (DOE), Office of Nuclear Energy. The report was authored by UT-Battelle under Contract No. DE-AC05-00OR22725 with the US Department of Energy. 


\section{SUMMARY}

The ability to make minimally intrusive measurements of process conditions has tremendous potential for improving system performance and control in applications such as nuclear power generation. Towards this end, emerging and evolving advanced manufacturing methods, such as additive manufacturing, present new opportunities for more seamlessly integrating sensing with structure. This technical report summarizes the progress of work performed to assess the feasibility of embedding commercial off-the-shelf(COTS) sensors in a metallic reactor core using advanced manufacturing methods. The progress of four research and development tasks are documented: 1) A survey of COTS sensors for nuclear applications that are candidates for embedded fabrication, 2) Development of a conceptual framework for investigating the feasibility of sensor embedment, 3) Definition of structural geometries and other characteristics that will represent compelling proof-of-concept, and 4) Preliminary prototyping of embedded sensors. For the purposes of this initial study, nuclear grade K-type thermocouples were selected for investigation of embedment methodologies. This sensor was selected as an initial candidate because it represents one of the simplest sensor configurations that can provide useful process information. A selective laser melting (SLM) additive manufacturing process was used to fabricate structures with complexity representative of the core design of the transformational challenge reactor (TCR) and methods were developed to embed a thermocouple with a complex two-dimensional routing path. There are many challenges associated with embedding sensors during the additive manufacturing process including securing the sensor in the structure, relocating the part in the additive machine if using a "pick and place" sensor placement method, mitigating the potential for powder contamination, optimizing energy deposition parameters to build as closely as possible around the sensor path and improve structural integrity of the part, and tuning energy deposition to mitigate thermally induced warpage of the sensor and part as well as potential for damaging the sensing device. Preliminary results indicate that it is feasible to integrate the sensor while minimally compromising the structural integrity of the part and preserving sensor performance. This first phase of this work focused on developing a workflow for embedding sensors and controlling energy deposition during the additive manufacturing process to better understand the build characteristics around the sensor. Future work will perform more in-depth characterization of prototype parts using X-ray computed tomography and scanning electron microscopy to better understand fabricated structures, performance testing of embedded sensors in high temperature environments, adding new embedded measurement modalities, embedding devices with

dissimilar materials in contact with additive powders, and the development of methods for embedding sensors with three-dimensional routing paths. 


\section{INTRODUCTION}

The ability to embed sensors directly into manufactured parts is an active research field with application to many industries. For the Transformational Challenge Reactor (TCR) project, embedded sensors hold the potential to provide direct temperature, radiation, and strain measurements within reactor core materials. The objective of this TCR task element is to demonstrate the feasibility of embedding commercial off-the-shelf (COTS) sensors in additively manufactured (AM) metal parts. Relevant sensors for nuclear applications were first surveyed to identify measurements that would be of value for the TCR, are currently available and have the potential to be embedded in the reactor core. Prospective additive manufacturing processes were then evaluated to identify a method that was suitable both for building representative reactor core parts and demonstrating the feasibility of embedment. It is noted that there are a number of different metal additive manufacturing processes such as selective laser melting (SLM), electron beam melting (EBM), directed energy deposition (DED) and binder jetting. Each of these methods employs a different build process and requires distinct energy deposition considerations. The concept of operations for embedding sensing devices therefore can differ depending on the method of additive manufacturing process used. For this study, nuclear grade K-type thermocouples were selected for embedding and SLS was selected as the AM process. The following sections will describe in detail the sensors available for embedding, design considerations, the concept of operations for embedding sensors, parametric manufacturing studies performed to quantitatively evaluate the additive manufacturing process, and the development of representative embedded sensor prototypes. 


\section{SENSOR SURVEY}

\subsection{SENSORS CONSIDERED FOR EMBEDDING}

This section provides a review of available COTS sensors for nuclear applications. Sensors for measuring core temperatures, thermal neutron flux, and strain or movement in the core are of primary interest. Typically, the sensor should have the smallest possible diameter to minimize compromise of structural integrity and facilitate incorporating within the component build. A good starting size for prototyping is $1 \mathrm{~mm}$ with a length as necessary to pass through the core region and with sufficient excess length to make connection.

Commercial sensor types are being considered because the emphasis is not on development and fabrication of sensors, but rather the embedding process. Below are possible manufacturers for embeddable temperature and neutron sensors.

\section{Temperature}

Several temperature transduction technologies are well developed for use in nuclear power such as RTDs and thermocouples, which have been in use for well over half a century in nuclear power applications. Both RTDs and thermocouples are useable to $550{ }^{\circ} \mathrm{C}$, although that temperature is approaching the upper limit (about $650{ }^{\circ} \mathrm{C}$ ) of commercial RTDs. In contrast, the type-N (nicrosil-nisil) thermocouple is acknowledged as the best suited for general deployment for continuous temperatures up to $900{ }^{\circ} \mathrm{C}$ and functional to $1300{ }^{\circ} \mathrm{C}$. For initial experimentation with embedding processes, the type-K thermocouple has been used because it is readily available and less expensive than the type-N. Both thermocouple types have similar characteristics as far as mechanical and thermal properties related to embedded fabrication. For actual reactor deployment, the type- $\mathrm{N}$ thermocouple is better suited as discussed below.

Type-N thermocouples exhibit a high Seebeck coefficient of $33 \mu \mathrm{V} / \mathrm{K}$; roughly double that of the Type C $(95 \% \mathrm{~W} / 5 \% \mathrm{Re}-74 \% \mathrm{~W} / 26 \% \mathrm{Re}$, by weight), which is a high-temperature thermocouple. Type-N thermocouples were developed in the 1980s to address the known instabilities of type K thermocouples (e.g., calibration drift). Type-N thermocouples tend to have lower drift than type $\mathrm{K}$ and other base-metal thermocouples and can handle higher temperatures than type $\mathrm{K}$ for short periods. Type $\mathrm{N}$ is also virtually free from nuclear transmutation effects. Low transmutation is achieved by eliminating manganese, cobalt, and iron from the thermocouple makeup. The types $\mathrm{K}$ and $\mathrm{N}$ are similar with respect to sensitivity and tolerance. Because of the chromium content of type $\mathrm{N}$ and even more so in type $\mathrm{K}$ thermocouples, they are not recommended for vacuum conditions at temperatures greater than $980{ }^{\circ} \mathrm{C}$. This limitation derives from two principal mechanisms: (1) in vacuum, a protective chromium oxide layer is not formed; (2) lacking this protective oxide layer, the constituent metals evaporate appreciably at high temperatures. It is therefore advisable to immerse the type $\mathrm{N}$ thermocouple in an inert protective atmosphere that impedes sublimation. Thus, the thermocouple should be enclosed in a gas-tight sheath filled with a non-reactive gas such as helium. Other thermocouples such as the non-letter-designation type $\mathrm{Nb} 1 \% \mathrm{Zr}-\mathrm{Mo}$ are also appropriate for the temperature and neutron flux but are not generally commercially available.

Error! Reference source not found, provides a list of sources of commercial temperature sensors appropriate for the TCR. 
Table 1 Listing of commercial temperature sensors for TCR application

\begin{tabular}{|c|c|c|c|c|c|c|c|c|}
\hline Manufacturer & $\begin{array}{l}\text { Model/ } \\
\text { Part No. }\end{array}$ & Technology & Temperature & Size & $\begin{array}{l}\text { Cost } \\
\text { (*est) }\end{array}$ & Availability & Electronics & Comment \\
\hline $\begin{array}{l}\text { Thermocoax } \\
\text { Nuclear }\end{array}$ & $\begin{array}{l}\text { Made to } \\
\text { order }\end{array}$ & Thermocouple & N/A & $\begin{array}{l}\text { Down } \\
\text { to } 1 \\
\mathrm{~mm}\end{array}$ & $\$ 300^{*}$ & $6 \mathrm{wks}$ & $\mathrm{TC}$ & $\begin{array}{l}\text { Nuclear } \\
\text { grade. } \\
\text { Will make } \\
\text { any TC } \\
\text { type }\end{array}$ \\
\hline Omega & $208-313$ & $\begin{array}{l}\text { Thermocouple } \\
\text { (N) }\end{array}$ & $1250^{\circ} \mathrm{C}$ & $\begin{array}{l}0.040 " \\
\text { dia } \mathrm{x} \\
12^{\prime \prime} \\
\text { long }\end{array}$ & $\$ 35$ & $\begin{array}{l}\text { Immediate to } \\
\text { 2-wk prep }\end{array}$ & $\mathrm{TC}$ & $\begin{array}{l}\text { Nicrobell } \\
\text { D Sheath } \\
\text { Not NQ }\end{array}$ \\
\hline Delta-M & $\begin{array}{l}\text { Made to } \\
\text { order }\end{array}$ & $\begin{array}{l}\text { Thermocouple } \\
\text { (N) }\end{array}$ & $1200^{\circ} \mathrm{C}$ & $\begin{array}{l}0.01 ” t \\
0 \\
0.25 "\end{array}$ & $\$ 100^{*}$ & 3 wks & $\mathrm{TC}$ & $\begin{array}{l}\text { Local } \\
\text { company } \\
\text { easy to } \\
\text { work with }\end{array}$ \\
\hline Delta-M & $\begin{array}{l}\text { Made to } \\
\text { order }\end{array}$ & Pt RTD & $650^{\circ} \mathrm{C}$ & $\begin{array}{l}0.062^{\prime \prime} \\
\text { to } \\
0.25^{\prime \prime}\end{array}$ & $\$ 200 *$ & 4 wks & $\begin{array}{l}\text { 4-wire RTD } \\
\text { input circuit }\end{array}$ & $\begin{array}{l}\text { Local } \\
\text { company } \\
\text { easy to } \\
\text { work with }\end{array}$ \\
\hline Nordic Sensors & $\begin{array}{l}\text { J11A24N } \\
5 \mathrm{G} 048 \mathrm{E} 1 \\
\end{array}$ & $\begin{array}{l}\text { Thermocouple } \\
\text { (N) }\end{array}$ & $500^{\circ} \mathrm{C}$ & $0.02 ”$ & $\$ 100^{*}$ & $3 \mathrm{wk}$ & $\mathrm{TC}$ & \\
\hline Nordic Sensors & $\begin{array}{l}\text { 1M1A14 } \\
\text { N1C2 }\end{array}$ & 4-wire Pt RTD & $500^{\circ} \mathrm{C}$ & $\begin{array}{l}0.079 " \\
4 "\end{array}$ & $\$ 250^{*}$ & $3 \mathrm{wk}$ & $\begin{array}{l}\text { 4-wire RTD } \\
\text { input circuit }\end{array}$ & \\
\hline Pyromation & $\begin{array}{l}\text { N14RM1 } \\
21,341\end{array}$ & $\begin{array}{l}\text { Thermocouple } \\
\text { (N) }\end{array}$ & $\mathrm{N} / \mathrm{A}$ & $\begin{array}{l}0.25 " \\
\text { dia }\end{array}$ & $\$ 100^{*}$ & $3 \mathrm{wk}$ & $\mathrm{TC}$ & $\begin{array}{l}\text { Ceramic } \\
\text { insulation } \\
\text { no sheath } \\
\end{array}$ \\
\hline Peak Sensors & $\begin{array}{l}\text { Made to } \\
\text { order }\end{array}$ & $\begin{array}{l}\text { Thermocouple } \\
\text { (N) }\end{array}$ & $1100^{\circ} \mathrm{C}$ & $\begin{array}{l}0.5 \\
\mathrm{~mm} \\
\text { dia. }\end{array}$ & $\$ 150^{*}$ & $4 \mathrm{wk}$ & $\mathrm{TC}$ & \\
\hline Thermometrics & $\begin{array}{ll}\begin{array}{l}\text { Made } \\
\text { order }\end{array} & \text { to } \\
\end{array}$ & $\begin{array}{l}\text { Thermocouple } \\
(\mathrm{N})\end{array}$ & $1260^{\circ} \mathrm{C}$ & N/A & N/A & N/A & $\mathrm{N} / \mathrm{A}$ & \\
\hline $\begin{array}{l}\text { Tempsens } \\
\text { Instruments }\end{array}$ & $\begin{array}{l}\text { Made to } \\
\text { order }\end{array}$ & $\begin{array}{l}\text { Thermocouple } \\
\text { (N) }\end{array}$ & $1200^{\circ} \mathrm{C}$ & $\begin{array}{l}0.25 \\
\mathrm{~mm}\end{array}$ & $\$ 100$ & 8 wks & $\mathrm{TC}$ & $\begin{array}{l}\text { Variety of } \\
\text { sheath } \\
\text { materials } \\
\text { available }\end{array}$ \\
\hline $\begin{array}{l}\text { AccuMac } \\
\text { Corporation }\end{array}$ & $\begin{array}{l}\text { Made to } \\
\text { order }\end{array}$ & $\begin{array}{l}\text { Standard } \\
\text { Platinum } \\
\text { Resistance } \\
\text { Thermometers } \\
\text { (SPRTs) }\end{array}$ & $670^{\circ} \mathrm{C}$ & $\begin{array}{l}6.35 \\
\mathrm{~mm} \\
(0.25\end{array}$ & $\$ 300$ & $4 \mathrm{wk}$ & $\begin{array}{l}\text { RTD input } \\
\text { circuitry }\end{array}$ & $\begin{array}{l}\text { Very } \\
\text { accurate } \\
( \pm 0.006 \\
\mathrm{K})\end{array}$ \\
\hline Technica & $\begin{array}{l}\text { T160 FBG } \\
\text { Made to } \\
\text { Order }\end{array}$ & $\begin{array}{l}\text { Optical fiber } \\
\text { with multipoint } \\
\text { temperature } \\
\text { using Bragg } \\
\text { Gratings }\end{array}$ & $700^{\circ} \mathrm{C}$ & $\begin{array}{l}0.125 \\
\mathrm{~mm} \\
\text { dia. }\end{array}$ & N/A & $6 \mathrm{wk}$ & $\begin{array}{l}\text { Proprietary } \\
\text { laser-based } \\
\text { system }\end{array}$ & \\
\hline Siemens & $\begin{array}{l}\text { SITRANS } \\
\text { TO500 }\end{array}$ & $\begin{array}{l}\text { Optical fiber } \\
\text { with multipoint } \\
\text { temperature } \\
\text { using Bragg } \\
\text { Gratings }\end{array}$ & $400^{\circ} \mathrm{C}$ & $\begin{array}{l}2 \mathrm{~mm} \\
\text { dia }\end{array}$ & N/A & $6 \mathrm{wk}$ & $\begin{array}{l}\text { Proprietary } \\
\text { laser-based } \\
\text { system }\end{array}$ & \\
\hline
\end{tabular}




\section{Neutrons ${ }^{1}$}

Neutron flux measurements are used in nuclear power reactors as a high-speed monitor of reactor power to enable rapid control system and safety system responses. Note that designers of advanced nuclear power reactors are pursuing passively safe designs that consequently do not have an emphasis on short-period safety measurements, which was required of light-water reactors. In LWRs, neutron flux measurement is calibrated against reactor output power as determined by long-term power calculations made using a combination of heat balance measurements on primary coolant, balance-of-plant, and sometimes by measurements of fuel composition. (The latter measurement is performed off-line with fuel samples taken from the reactor as would be possible with liquid fueled reactors.) For high-temperature reactors, neutron detection can take place outside of the core region and can be performed using the same detectors employed in existing light-water power plants. Table 2 provides a brief description of the advantages and uses of commonly used neutron detectors.

Table 2 Brief description of common neutron detectors used in nuclear reactors.

\begin{tabular}{|c|c|c|}
\hline Neutron Detector Type & Advantage/Disadvantage & $\begin{array}{l}\text { Primary Usage in Advanced } \\
\text { Reactors }\end{array}$ \\
\hline $\begin{array}{l}\text { Ion Chambers } \\
\mathbf{B F}_{\mathbf{3}} \mathbf{G a s}\end{array}$ & $\begin{array}{l}\text { Can be used in pulse counting mode. Efficient } \\
\text { conversion of neutrons to ionization. High radiation } \\
\text { levels cause gas dissociation. Rapid burn-out and } \\
\text { self-heating in high flux environment due to high } \\
\text { neutron cross section. }\end{array}$ & $\begin{array}{l}\text { The } \mathrm{BF}_{3} \text { ion chamber is useable for } \\
\text { source (startup) range for pulse } \\
\text { counting. Not for partial or full } \\
\text { power operation. }\end{array}$ \\
\hline $\begin{array}{l}\text { Ion Chambers } \\
{ }^{10} \mathbf{B} \text { Lined }\end{array}$ & $\begin{array}{l}\text { Can be used in pulse counting mode for startup and } \\
\text { in current mode for higher flux levels. Rapid burn- } \\
\text { out and self-heating in high flux environment. }\end{array}$ & $\begin{array}{l}\text { Limited to lower power ranges } \\
\text { because of high neutron cross } \\
\text { section. }\end{array}$ \\
\hline $\begin{array}{l}\text { Ion Chambers } \\
{ }^{3} \mathbf{H e}\end{array}$ & $\begin{array}{l}\text { Can be operated in any mode (ionization chamber, } \\
\text { proportional, or Geiger-Mueller) depending on the } \\
\text { anode voltage. Most efficient in converting neutrons } \\
\text { to ionizations. Low reaction to gamma rays. } \\
\text { Disadvantage is the unavailability and cost of }{ }^{3} \mathrm{He} \text {. } \\
\text { Rapid burn-out and self-heating in high flux } \\
\text { environment due to high neutron cross section. }\end{array}$ & Initial fueling startup only. \\
\hline $\begin{array}{l}\text { Compensated Ion } \\
\text { Chambers }\end{array}$ & $\begin{array}{l}\text { Compensation is to reduce sensitivity to gamma } \\
\text { rays - all ion chambers naturally respond to gamma } \\
\text { rays. The typical compensated detector comprises } \\
\text { two separate chambers, one sensitive to gammas and } \\
\text { neutrons, the other to gammas only. Currents from } \\
\text { each chamber are subtracted locally so that the } \\
\text { detector output is the difference current, which is the } \\
\text { neutron response. Useful for intermediate range } \\
\text { when gamma compensated. }\end{array}$ & $\begin{array}{l}\text { Useful for intermediate range when } \\
\text { gamma compensated. }\end{array}$ \\
\hline
\end{tabular}

\footnotetext{
${ }^{1}$ W. H. Todt, Sr., "Characteristics of Self-Powered Neutron Detectors Used in Power Reactors," 1997.
} 


\begin{tabular}{|c|c|c|}
\hline Fission Chambers & $\begin{array}{l}\text { Fission chambers are a type of ion chamber in which } \\
\text { the reaction surface is coated with a thin layer of }{ }^{235} \mathrm{U} \text {. } \\
\text { Because the }{ }^{235} \mathrm{U} \text { coating must be kept very thin due } \\
\text { to limited fission product penetration distances, the } \\
\text { chamber exhibits low detection efficiency. The } \\
\text { fissionable material is consumed in the neutron flux. } \\
\text { Some depletion mitigation is possible by including } \\
\text { fertile material such as }{ }^{238} \mathrm{U} \text {. Diameters of fission } \\
\text { chambers are smaller than other ion chambers. } \\
\text { Fission counters have the highest insensitivity to } \\
\text { gamma rays. Larger pulse size generated by fission } \\
\text { counters allows locating preamplifier electronics } \\
\text { further away from harsh environment. }\end{array}$ & $\begin{array}{l}\text { Intermediate and power range } \\
\text { neutron fluxes. Fission chambers } \\
\text { many be used in-core or ex-vessel. } \\
\text { When used in-core especially, they } \\
\text { are made movable to extend lifetime } \\
\text { by removing them from high neutron } \\
\text { flux regions. }\end{array}$ \\
\hline $\begin{array}{l}\text { Fast Neutron Detectors } \\
\text { (applicable to fast } \\
\text { spectrum reactors) }\end{array}$ & $\begin{array}{l}\text { The capture cross section of }{ }^{10} \mathrm{~B} \text { is reduced by } 500 \\
\text { and }{ }^{235} \mathrm{U} \text { by } 1100 \text { with fast as compared to thermal } \\
\text { neutrons. One method of detecting fast neutrons is to } \\
\text { include moderation in the detector. However, } \\
\text { generally larger detectors are employed instead. }\end{array}$ & $\begin{array}{l}\text { Startup of fast spectrum reactors. } \\
\text { Thermalize and detect will generally } \\
\text { be used ex-core for power range } \\
\text { operation. }\end{array}$ \\
\hline $\begin{array}{l}\text { Self-Power Neutron } \\
\text { Detectors } \\
\quad \text { (SPND) }\end{array}$ & $\begin{array}{l}\text { Used effectively as in-core flux monitors for close to } \\
50 \text { years. Advantages are small size, low cost, and } \\
\text { simple electronics required for measurement readout. } \\
\text { Disadvantage is the delayed response and small } \\
\text { signal size. }\end{array}$ & Excellent for core flux mapping. \\
\hline $\begin{array}{l}\text { Gamma } \quad \text { Flux } \\
\text { Detectors }\end{array}$ & $\begin{array}{l}\text { Not suitable for startup or low power } \\
\text { operation because of bias from background (fission- } \\
\text { product decay) radiation. Only that fraction of the } \\
\text { gamma flux which originates in prompt processes } \\
\text { (capture and fission) varies with the power level; } \\
\text { gamma radiation is also emitted by decay processes } \\
\text { originating from fission products. Above the } \\
\text { intermediate power level, gamma intensity becomes } \\
\text { proportional to reactor power. Gamma detector } \\
\text { design can be based on ionization or gamma heating. }\end{array}$ & $\begin{array}{l}\text { Measurement of reactor } \\
\text { power distribution in the } 5 \text { percent to } \\
150 \text { percent range. }\end{array}$ \\
\hline
\end{tabular}

For all reactor types, neutron flux monitoring is required during startup. At startup, the neutron flux begins very low - corresponding to source intensity. These low neutron counts become amplified as reactivity is increased (by control rod withdrawal for example) and neutron amplification occurs. The initial measurement is made with a high-efficiency neutron counting instrument, usually deployed in-core. To prevent burnout of the sensitive counter (e.g., fission counter), the instrument is retracted to a significantly lower count-rate region of the reactor. In the case of the TCR, which has a short operating life, such retraction may not be necessary. Thermal-spectrum reactors may also employ local power-range monitors to characterize power distribution within core. These power distribution monitors typically are neutron based but can be based on gamma measurements for high power levels. These in-core monitors confirm the validity of nucleonic and thermal hydraulic modeling and simulation and watch for unplanned anomalous events in the core (e.g., loose parts or unsymmetrical fuel burn). Neutron detector characteristics as they pertain to reactor uses are shown in Table 3. The self-powered neutron detector (SPND) is especially applicable to the TCR because of its small size compared with ion chambers and fission chambers. 
Table 3 Neutron detector characteristics and uses.

\begin{tabular}{|c|c|c|c|c|c|c|c|}
\hline \multirow[b]{2}{*}{$\begin{array}{l}\text { Measurement } \\
\text { Function }\end{array}$} & \multicolumn{7}{|c|}{ Detector Characteristic } \\
\hline & $\begin{array}{c}\text { Sensitivity } \\
\text { or Detection } \\
\text { Efficiency }\end{array}$ & $\begin{array}{c}\text { Signal } \\
\text { Response } \\
\text { Time }\end{array}$ & $\begin{array}{c}\text { Survivability } \\
\text { in Reactor } \\
\text { Environment }\end{array}$ & $\begin{array}{c}\text { Device } \\
\text { Lifetime }\end{array}$ & $\begin{array}{l}\text { Physical } \\
\text { (Note: } \\
\text { fast spectrum } \\
\text { reactors } \\
\text { require larger } \\
\text { detectors than } \\
\text { thermal } \\
\text { reactors.) }\end{array}$ & In-Core & $\begin{array}{c}\text { Ex- } \\
\text { Vessel }\end{array}$ \\
\hline $\begin{array}{l}\text { Count-Rate } \\
\text { Data During } \\
\text { Approach to } \\
\text { Critical } \\
\\
\text { (first fuel } \\
\text { start) }\end{array}$ & $\begin{array}{l}\text { Pulse } \\
\text { counting } \\
\text { detector } \\
\text { measures in } \\
\text { counts per } \\
\text { second } \\
\text { (typically } \\
\text { less than } 2 \text { to } \\
\text { over } 1000 \\
\text { cps) }\end{array}$ & $200 \mu \mathrm{s}$ & $\begin{array}{l}\text { Usually the } \\
\text { startup } \\
\text { detector is } \\
\text { movable and } \\
\text { is removed } \\
\text { from the core } \\
\text { before assent } \\
\text { to power } \\
\text { because it } \\
\text { cannot tolerate } \\
\text { high neutron } \\
\text { flux. }\end{array}$ & $\begin{array}{l}\text { Indefinite } \\
\text { lifetime if } \\
\text { removed } \\
\text { from the } \\
\text { core during } \\
\text { normal } \\
\text { operation. }\end{array}$ & $\begin{array}{l}\text { Small } \\
\text { diameter for } \\
\text { mounting to } \\
\text { movable } \\
\text { platform. } \\
\text { Diameter } 1- \\
2 \mathrm{~cm} . \text { Length } \\
10-20 \mathrm{~cm} .\end{array}$ & $\begin{array}{l}\text { Neutron counts } \\
\text { measured at initial } \\
\text { fueling are } \\
\text { essential to } \\
\text { characterize } \\
\text { approach to } \\
\text { critical. In-core } \\
\text { measurement is } \\
\text { usually preferred. }\end{array}$ & $\begin{array}{l}\text { Ex vessel } \\
\text { startup } \\
\text { measure } \\
\text { ments can } \\
\text { be made } \\
\text { if the } \\
\text { source is } \\
\text { placed } \\
\text { near the } \\
\text { wall } \\
\text { proximall } \\
\text { y to the } \\
\text { detector. }\end{array}$ \\
\hline $\begin{array}{l}\text { Count-Rate } \\
\text { Data During } \\
\text { Startup } \\
\text { (startup after } \\
\text { initial fueling) }\end{array}$ & $\begin{array}{l}\text { Measured in } \\
\text { counts per } \\
\text { second } \\
\text { (typically } \\
\text { less than } 10 \\
\text { to } 1000 \mathrm{cps} \text { ). } \\
\text { Similar or } \\
\text { identical to } \\
\text { the detector } \\
\text { used during } \\
\text { initial } \\
\text { fueling. } \\
\text { However, } \\
\text { extends to } \\
\text { continuous } \\
\text { range- } \\
1 \times 10^{6} \mathrm{n} / \mathrm{cm}^{2}- \\
\mathrm{s} \text {. }\end{array}$ & $500 \mu \mathrm{s}$ & $\begin{array}{l}\text { Same as first } \\
\text { start: startup } \\
\text { detector is } \\
\text { removed from } \\
\text { the core before } \\
\text { assent to } \\
\text { power because } \\
\text { it cannot } \\
\text { tolerate high } \\
\text { flux. }\end{array}$ & $\begin{array}{l}\text { Same as } \\
\text { first start. }\end{array}$ & $\begin{array}{l}\text { Same as first } \\
\text { start. }\end{array}$ & $\begin{array}{l}\text { Neutron counts } \\
\text { for reactor startup } \\
\text { measured after } \\
\text { initial criticality } \\
\text { characterization } \\
\text { may be in-core or } \\
\text { ex-core. }\end{array}$ & $\begin{array}{l}\text { Ex vessel } \\
\text { startup } \\
\text { measure } \\
\text { ments can } \\
\text { be made } \\
\text { if the } \\
\text { source is } \\
\text { placed } \\
\text { near the } \\
\text { wall in } \\
\text { proximity } \\
\text { to the } \\
\text { detector. }\end{array}$ \\
\hline
\end{tabular}




\begin{tabular}{|c|c|c|c|c|c|c|c|}
\hline \multirow[b]{2}{*}{$\begin{array}{l}\text { Measurement } \\
\text { Function }\end{array}$} & \multicolumn{7}{|c|}{ Detector Characteristic } \\
\hline & $\begin{array}{c}\text { Sensitivity } \\
\text { or Detection } \\
\text { Efficiency }\end{array}$ & \begin{tabular}{|c|} 
Signal \\
Response \\
Time
\end{tabular} & $\begin{array}{c}\text { Survivability } \\
\text { in Reactor } \\
\text { Environment }\end{array}$ & $\begin{array}{c}\text { Device } \\
\text { Lifetime }\end{array}$ & \begin{tabular}{|}
$\begin{array}{c}\text { Physical } \\
\text { (Note: }\end{array}$ \\
fast spectrum \\
reactors \\
require larger \\
detectors than \\
thermal \\
reactors.)
\end{tabular} & In-Core & $\begin{array}{c}\text { Ex- } \\
\text { Vessel }\end{array}$ \\
\hline $\begin{array}{l}\text { Indicate } \\
\text { Rapid Power } \\
\text { Level Change } \\
\text { (calibrated } \\
\text { against } \\
\text { thermal power } \\
\text { measurement) }\end{array}$ & $\begin{array}{l}1 \times 10^{7} \text { to } \\
1 \times 10^{10} \\
\left(\mathrm{n} / \mathrm{cm}^{2}-\mathrm{s}\right)\end{array}$ & $1 \mathrm{~ms}$ & $\begin{array}{l}\text { Survive for } 10 \\
\text { years. Ex- } \\
\text { vessel location } \\
\text { required with } \\
\text { operating } \\
\text { temperature of } \\
\text { less than } \\
200^{\circ} \mathrm{C}\end{array}$ & $\begin{array}{l}\begin{array}{l}1.7 \times 10^{19} \mathrm{nvt} \\
\quad(10 \\
\text { full power } \\
\text { years })\end{array}\end{array}$ & $\begin{array}{l}\text { Large volume } \\
\text { is not a } \\
\text { problem }\end{array}$ & $\begin{array}{l}\text { Not appropriate } \\
\text { for all reactor } \\
\text { types }\end{array}$ & $\begin{array}{l}\text { Can be } 1 \\
-3 \text { inches } \\
\text { diameter } \\
\text { and up to } \\
\text { length of } \\
\text { vessel. } \\
\text { Lower } \\
\text { temperatu } \\
\text { re of } 200 \\
{ }^{\circ} \mathrm{C} \text { is } \\
\text { feasible. }\end{array}$ \\
\hline \begin{tabular}{|l|} 
Confirm \\
Calculated \\
Core \\
Performance \\
(spatial flux \\
information)
\end{tabular} & $\begin{array}{l}1 \times 10^{8} \text { to } \\
1 \times 10^{13} \\
\left(\mathrm{n} / \mathrm{cm}^{2}-\mathrm{s}\right)\end{array}$ & $10 \mathrm{~s}$ & $\begin{array}{l}\text { Survive for } 10 \\
\text { years at } \\
\text { elevated } \\
\text { temperatures } \\
(\text { above } \\
\left.550^{\circ} \mathrm{C}\right)\end{array}$ & $\begin{array}{l}1.7 \times 10^{22} \mathrm{nvt} \\
(10 \text { full } \\
\text { power } \\
\text { years })\end{array}$ & $\begin{array}{l}\text { Smaller size } \\
\text { may be needed } \\
\text { to discriminate } \\
\text { flux variations }\end{array}$ & $\begin{array}{l}\text { Small number of } \\
\text { detectors may be } \\
\text { placed in regions } \\
\text { of core }\end{array}$ & \begin{tabular}{|l|} 
Likely \\
ex-vessel \\
placemen \\
$\mathrm{t}$ will not \\
provide \\
detailed \\
in-core \\
spatial \\
data.
\end{tabular} \\
\hline $\begin{array}{l}\text { Map Core } \\
\text { Flux } \\
\text { Distribution } \\
\text { (likely } \\
\text { measurement } \\
\text { only } \\
\text { performed on } \\
\text { test reactor to } \\
\text { confirm } \\
\text { predicted } \\
\text { values.) }\end{array}$ & $\begin{array}{l}1 \times 10^{10} \text { to } \\
1 \times 10^{13} \\
\left(\mathrm{n} / \mathrm{cm}^{2}-\mathrm{s}\right)\end{array}$ & $\begin{array}{l}100 \mathrm{~s} \\
\text { (rapid } \\
\text { response } \\
\text { not } \\
\text { important } \\
\text { ) }\end{array}$ & $\begin{array}{l}\text { Survive for } \\
\text { test duration in } \\
\text { reactor }\end{array}$ & $\begin{array}{l}1.7 \times 10^{22} \mathrm{nvt} \\
(10 \text { full } \\
\text { power } \\
\text { years })\end{array}$ & \begin{tabular}{|l} 
Can be a \\
SPND with \\
diameters to \\
$1.5 \mathrm{~mm}$. Small \\
size and \\
movable \\
needed to map \\
axial \\
distribution.
\end{tabular} & $\begin{array}{l}\text { Only makes sense } \\
\text { for in-core } \\
\text { operation }\end{array}$ & $\begin{array}{ll} & \mathrm{N}\end{array}$ \\
\hline $\begin{array}{l}\text { Provide an } \\
\text { indication of } \\
\text { fuel, } \\
\text { moderator, } \\
\text { and coolant } \\
\text { integrity }\end{array}$ & $\begin{array}{l}1 \times 10^{8} \text { to } \\
1 \times 10^{13} \\
\left(\mathrm{n} / \mathrm{cm}^{2}-\mathrm{s}\right)\end{array}$ & $1 \mathrm{~s}$ & $\begin{array}{l}\text { Survive for } 10 \\
\text { years }\end{array}$ & $\begin{array}{l}1.7 \times 10^{22} \mathrm{nvt} \\
(10 \text { full } \\
\text { power } \\
\text { years })\end{array}$ & $\begin{array}{l}\text { Small size } \\
\text { may not be } \\
\text { important }\end{array}$ & $\begin{array}{l}\text { The premise is } \\
\text { that the expected } \\
\text { in-core flux/power } \\
\text { distribution will } \\
\text { not develop if all } \\
\text { of the parts are not } \\
\text { working properly }\end{array}$ & \begin{tabular}{|l} 
Could \\
also be \\
mounted \\
ex-vessel
\end{tabular} \\
\hline $\begin{array}{l}\text { Identify } \\
\text { Loose Parts } \\
\text { and } \\
\text { Structural } \\
\text { Integrity }\end{array}$ & $\begin{array}{l}1 \times 10^{8} \text { to } \\
1 \times 10^{13} \\
\left(\mathrm{n} / \mathrm{cm}^{2}-\mathrm{s}\right)\end{array}$ & $\begin{array}{l}100 \mu \mathrm{s} \\
\text { (high } \\
\text { frequency } \\
\text { response } \\
\text { necessary } \\
\text { ) }\end{array}$ & $\begin{array}{l}\text { Survive for } 10 \\
\text { years }\end{array}$ & $\begin{array}{l}1.7 \times 10^{22} \mathrm{nvt} \\
(10 \text { full } \\
\text { power } \\
\text { years })\end{array}$ & $\begin{array}{l}\text { Small size } \\
\text { may not be } \\
\text { important }\end{array}$ & Can be in core & $\begin{array}{l}\text { Can be ex } \\
\text { core }\end{array}$ \\
\hline
\end{tabular}


Table 4 provides a list companies that manufacture SPNDs. Note, it is difficult to determine price of detectors from any vendor without going through a quotation process. Likewise, the availability column is just an estimate. SPNDs are more of a custom fabrication to a customer's specification rather than an offthe-shelf product like a thermocouple or RTD.

Table 4 Commercial neutron detectors.

\begin{tabular}{|c|c|c|c|c|c|c|c|c|}
\hline Manufacturer & $\begin{array}{c}\text { Model } \\
\text { / Part } \\
\text { No. } \\
\end{array}$ & Technology & Size & Availability & Electronics & Lifetime & $\begin{array}{c}\text { Country } \\
\text { of } \\
\text { Origin } \\
\end{array}$ & Comment \\
\hline $\begin{array}{l}\text { Tempsens } \\
\text { Instruments }\end{array}$ & N/A & $\begin{array}{l}\text { Rhodium } \\
\text { emitter }\end{array}$ & $\begin{array}{l}1.6 \\
\mathrm{~mm} x \\
10 \\
\mathrm{~mm}\end{array}$ & 12 weeks & $\begin{array}{l}\text { Charge- } \\
\text { sensitive } \\
\text { preamplifier } \\
\text { with shapers } \\
\text { and multi- } \\
\text { channel } \\
\text { analyzer }\end{array}$ & $10 y$ & India & $\begin{array}{l}\text { Body In-600 } \\
\text { Vanadium } \\
\text { and rhodium } \\
\text { typical } \\
\text { emitter } \\
\text { materials. } \\
\text { Model } \\
\text { designation } \\
\text { depends on } \\
\text { numerous } \\
\text { parameters }\end{array}$ \\
\hline $\begin{array}{l}\text { KWD Nuclear } \\
\text { Instruments }\end{array}$ & $\begin{array}{l}5503- \\
\text { Co- } \\
210\end{array}$ & $\begin{array}{l}\text { SPND } \\
\text { Cobalt }\end{array}$ & $\begin{array}{l}3.7 \mathrm{~m} \\
\mathrm{~m} \mathrm{x} \\
100 \mathrm{~m} \\
\mathrm{~m}\end{array}$ & 8 weeks & $\begin{array}{l}\text { Support } \\
\text { electronics } \\
\text { available }\end{array}$ & $20 y$ & Sweden & $\begin{array}{l}\text { Cobalt, } \\
\text { rhodium, } \\
\text { vanadium, } \\
\text { lead, and } \\
\text { platinum } \\
\text { available } \\
\text { http://www. } \\
\text { kwdnucleari } \\
\text { nstruments.s } \\
\text { e/uploaded_f } \\
\text { iles/Specific } \\
\text { ations- } \\
\text { SPND- } \\
\text { 20181024.p } \\
\text { df?v201810 } \\
\text { 24122755 }\end{array}$ \\
\hline $\begin{array}{l}\text { Thermocoax } \\
\text { Nuclear }\end{array}$ & N/A & SPND & $\begin{array}{l}1.5 \\
\mathrm{~mm}\end{array}$ & 10 weeks & $\begin{array}{l}\text { Support } \\
\text { electronics } \\
\text { available }\end{array}$ & $20 \mathrm{y}$ & France & $\begin{array}{l}\text { Several } \\
\text { models } \\
\text { available } \\
\text { including } \\
\text { gamma } \\
\text { thermometer } \\
\text { s. } \\
\text { USA office } \\
\text { Smyrna GA }\end{array}$ \\
\hline
\end{tabular}




\begin{tabular}{|l|l|l|l|l|l|l|l|l|}
\hline $\begin{array}{l}\text { Mirion } \\
\text { Technologies }\end{array}$ & $\begin{array}{l}\text { Pared } \\
\text { with } \\
\text { electro } \\
\text { nics } \\
\text { packa } \\
\text { ges }\end{array}$ & SPND & $\begin{array}{l}1.5 \\
\mathrm{~mm}\end{array}$ & N/A & $\begin{array}{l}\text { PDM 501, } \\
502\end{array}$ & $20 \mathrm{y}$ & France & $\begin{array}{l}400^{\circ} \mathrm{C} \max \\
\text { temp }\end{array}$ \\
\hline Westinghouse & N/A & $\begin{array}{l}\text { SPND, } \\
\text { vanadium }\end{array}$ & $2 \mathrm{~mm}$ & N/A & N/A & $20 \mathrm{y}$ & USA & \\
\hline $\begin{array}{l}\text { Ari Industries } \\
\text { Inc.Japan }\end{array}$ & N/A & N/A & N/A & N/A & N/A & N/A & Japan & \\
\hline
\end{tabular}

\section{$\underline{\text { Strain }}$}

Measurement of core structure strain and movement is advisable especially for prototype systems because of the lack of history regarding development of additively manufactured nuclear reactor cores. Optical fibers offer several methods of strain read out (e.g., inscribed fiber Bragg gratings) and are available commercially. However, the environmental factor of high fluence of neutrons and gammas as found in the core of a reactor makes deployment of optical fibers difficult. Recently, NIST has made strides in formulating a radiation tolerant material. ${ }^{2}$ Unfortunately, no commercial products are available for immediate use in the TCR.

${ }^{2}$ Zeeshan Ahmed, Lonnie T. Cumberland, Nikolai N. Klimov, Ileana M. Pazos, Ronald E. Tosh and Ryan Fitzgerald. Assessing Radiation Hardness of Silicon Photonic Sensors. Scientific Reports volume 8, Article number: 13007 (2018) DOI: 10.1038/s41598-018-31286-9. 


\section{CONCEPTUAL FRAMEWORK FOR EVALUATING EMBEDMENT FEASIBILITY USING ADDITIVE MANUFACTURING}

This section describes the considerations and methodology used to evaluate the feasibility of embedding a COTS sensor in additively manufactured parts representative of prospective TCR core design structural elements. The sensor selected for this first phase of evaluation was a nuclear K-type thermocouple with mineral insulation and maximum operating temperature limit of $700^{\circ} \mathrm{C}$. As discussed previously, the type$\mathrm{K}$ and $\mathrm{N}$-type are nearly identical in mechanical and thermal characteristics, the type $\mathrm{K}$ being more common. A systematic approach was taken to define design requirements and evaluate suitable manufacturing methods that achieve the routing complexity needed for sensor placement while minimally affecting the structural integrity of the core and ensuring reliable sensor operation.

\subsection{EMBEDDED SENSOR DESIGN CONSIDERATIONS}

\subsubsection{Nuclear application considerations}

Determining the necessary characteristics of in-core reactor sensors starts with an understanding of core design. A notable feature of the Transformational Challenge Reactor (TCR) is that it is formed through additive manufacturing. Of particular note are the operating temperatures of $425{ }^{\circ} \mathrm{C}$ to $550{ }^{\circ} \mathrm{C}$, core materials of Stainless Steel and Silicon Carbide, and operating lifetime of only about 10 hours. Of particular importance are measurements of temperature distributions, heat fluxes, and neutron fluxes during this short operation horizon. For the compact core design, it is desirable to measure these parameters at the closest point of significance without disturbing structural integrity, thermal performance, or nucleonic performance.

A strategy applied in selecting and placing in-core sensors in commercial power reactors is to minimize the number of in-vessel sensors because the environment is harsh from a combination of temperature, pressure, and radiation effects. In addition, access to a commercial reactor core is limited to refueling periods (typically spaced 18 to 24 months) so that a failed sensor cannot be serviced except during those periods - shutting down the plant comes at great expense. Therefore, most of the measurements in LWRs are made external to the reactor vessel. In addition, there is great concern that components in the reactor core can become dislodged and become destructive hammers in the coolant flow path. Therefore, less is better.

For the TCR, the principal in-core sensors would likely measure temperatures and neutron fluxes. In-core measurements of helium gas flow and pressure would not be particularly useful. However, position and strain measurement may have some value pertaining to fuel degradation or unwanted movement in the core structure. Especially required for the TCR would be a neutron detector for monitoring approach-tocriticality during startup. Almost always, startup neutron detectors, being sensitive enough to measure low neutron count rates at startup, are subject to damage at higher power level; they are therefore usually withdrawn to prevent burnout as the power level increases. Removal for the TCR application may not be necessary because of the short operating period. 
Multiple-point rather than single-point measurements are desirable for an experimental reactor core owing to the need to confirm modeling and simulation predictions. Embeddable sensors such as thermocouples and self-powered neutron detectors (SPNDs) are single-point measurements. Some sensor technologies such as those based on ultrasonic and optical fibers can be configured to deploy multiple measurement zones. Optical fiber temperature measurement using multiple Bragg Gratings is an excellent example of a method to obtain perhaps hundreds of measurements along a single fiber. The difficulty with optical fibers is their darkening over time resulting from gamma dose. Fiber-optic darkening can be remedied by thermal annealing (regeneration); however, off-the-shelf products for direct in-core use are not available.

\subsubsection{Additive manufacturing considerations}

The primary value of using additive manufacturing for producing part geometries with embedded sensors is based on the ability to produce complicated two-dimensional or three-dimensional sensor routing paths internal to a part while minimally affecting its structural integrity. The simple example shown in Figure 1 below illustrates this benefit. While the thermocouple groove depicted in Figure 1a could have been created using a conventional milling procedure, adding the overlying structure shown in figure $1 \mathrm{~b}$ would have required either a brazing operation, which would result in a weaker bond between the two halves of the assembly, or circumferential welds at the outer boundaries of the part interfaces. Multi-component conventional manufacturing options compromise the structural integrity compared with monolithic structure because of the addition of potentially weak interfaces. In contrast to the conventional approach, additive manufacturing can be used to seamlessly deposit material on the bottom section to form the sensor groove, as depicted in Figure 1c. The mechanical material properties are approximately equivalent to the base material. It is also noted that it is possible to produce geometries for embedded sensors that cannot be fabricated using conventional methods.

a.

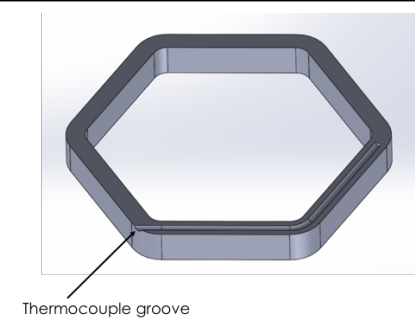

b.

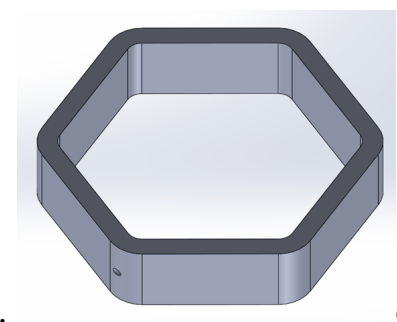

c.

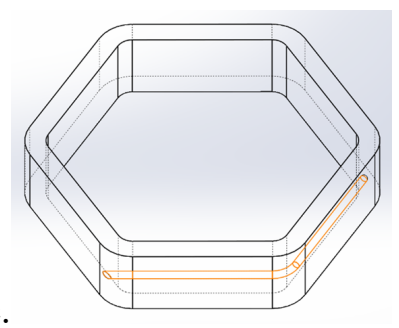

Figure 1 Embedded sensor groove example

For the example in Figure 1, the sheath for the thermocouple or the entire thermocouple assembly can be inserted into the groove at the fabrication stage shown in Figure 1a. This is often referred to as a pick and place approach because the additive build is temporarily stopped so the sensor can be attached to the assembly at an intermediate build point. The build is then resumed to complete the part fabrication. A significant challenge associated with this approach involves securing the sensor to the part. The attachment step is critical because the additive process introduces tremendous localized thermal gradients that can shift and warp the part and the sensor. Part movement can produce a final geometry that differs from what was intended, or it can interfere with the build process and adversely affect the additive system apparatus. In a powder bed additive manufacturing process, for example, a layer by layer build process is used. Out of plane warpage or shifting out of plane can produce mechanical interference and damage the rake or roller system used to produce a uniform powder bed layer. 
There are additional challenges associated with the pick-and-place approach such as precision control of energy deposition to avoid damaging the embedded component and preventing build-powder contamination when dissimilar materials from the part are proximal to the melt pool created by the energy deposition. Excessive embedded part temperature can result in mechanical damage (e.g. melting). At less extreme temperatures, sensor performance may be compromised by inadvertent property changes such as material diffusion. Dissimilar materials, melted or sublimated from the embedded component, must not be intermixed with the AM powder. A change in powder composition produces a change in its melt properties resulting in a loss of control of the AM process.

An alternative sensor embedment approach is to insert the sensor into the groove after the part is additively fabricated. A tight tolerance between the part and the embedded component typically requires that the groove created in the part must be post-processed to remove burrs or roughness that impedes component insertion. No methods exist for deburring or post-machining to refining as-built geometries for complex grooves in additive parts. Post-fabrication part insertion such as a sheathed thermocouple may not be feasible because of mechanical resistance. Methods for overcoming these issues continue to be a research topic.

Initial project efforts focused on reducing and isolating the challenges associated with embedding sensors in additively manufactured parts. A risk mitigation strategy was adopted to more methodically investigate elements of the sensor embedment process and develop proven approaches for addressing the individual challenges. Aspects of sensor embedment for this study were as follows: 1) Pick and place methodologies for incorporating and securing the sensor in the build, 2) Demonstration of the feasibility of complex 2-dimensional embedded sensor routing within the part that can't otherwise be achieved using conventional manufacturing processes, 3) Minimizing the dimensions of the sensor in the part, and 4) Characterizing the control of AM energy deposition and its influence on both the precision of the build geometry and likelihood of damaging the sensor. Not addressed specifically in this study, but topics of future interest include to following: 1) Tools and methods for post-AM build deburring and insertion of embedded sensors, 2) Procedures for incorporating sensors with dissimilar materials in contact with AM powders during the AM process, and 3) Procedures for embedding sensors with complex 3-dimensional routing paths.

Nuclear grade thermocouples were selected for embedment studies because they satisfied all the criteria of interest and avoided the additional challenges that were not of interest at this stage of the project. Specifically, they are available in very small diameters so as to be minimally intrusive, they are flexible and suitable for complex path routing. They are available with sheath materials nominally identical to metal AM powders. Such materials avoid placing dissimilar materials in direct contact with AM powders.

\subsection{MANUFACTURING PROCESS AND SENSOR ROUTING}

\subsubsection{Manufacturing process}

Sensor embedding using AM requires understanding AM processes from several perspectives - applied energy, mechanical sequencing, materials, thermodynamics, and the resulting forces. Only processes associated with metal AM were considered: specifically, the two categories powder bed fusion (PBF) and direct energy deposition (DED). PBF comprises a bed of metal powder that becomes fused together layer by layer with a focused energy source. The energy source can be a laser [selective laser melting (SLM)] or an electron beam [electron beam melting (EBM)]. PBF processes usually exhibit a greater control over dimensional tolerances given good characterization of the focused energy source. For DED processes, the metal powder is delivered by a nozzle with either laser or electron beam energy source. DED processes allow greater flexibility in build geometries as the parts are not limited to planar build parameters. 
The initial work in demonstrating sensor embedding was accomplished by a SLM system. The laser source and part orientation are shown in Figure 2. The figure depicts laser and associated melt pool.

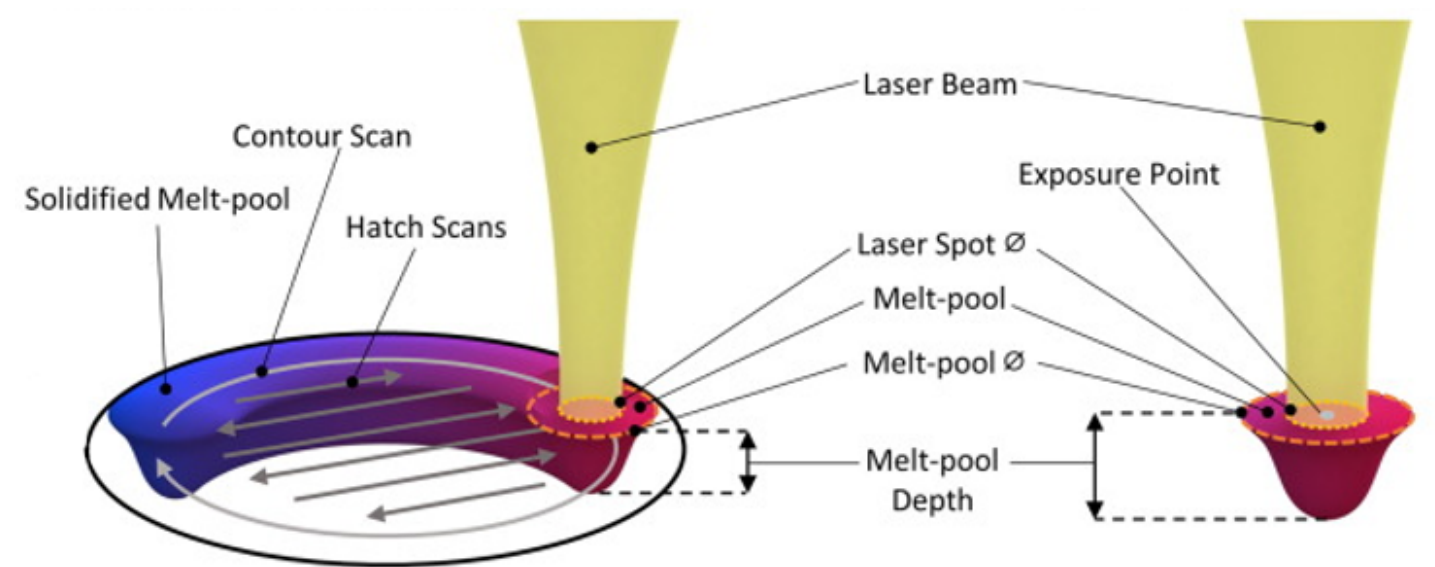

Figure 2: Diagram of SLM metal 3D printing ${ }^{3}$

The parameters are as follows for the SLM process in this project:

- Melt-pool diameter: $100 \mu \mathrm{m}$

- Melt-pool depth (average): $120 \mu \mathrm{m}$

- Single powder layer thickness: $50 \mu \mathrm{m}$

- Powder particulate size: $15-45 \mu \mathrm{m}$

The laser is focused to melt a single powder layer as well as about one-and-a-half layers below it. This dispersion helps to ensure each layer is well fused to previously printed layers.

\subsubsection{Placement of Sensor}

SLM AM, an inherently planar printed process permits meandering grooves to be created; however, they cannot be fully three-dimensional in nature. A sensor with a circular cross-section requires printing a groove first. After creating the groove, printing is suspended. The sensor is embedded. Then the printing process continues over the top of the sensor. This process is referred to as a "Stop-and-Go" process. ${ }^{4}$. Error! Reference source not found, shows several options for carrying out this process.

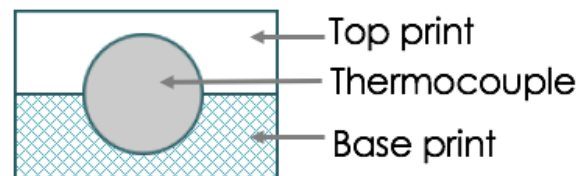

1.

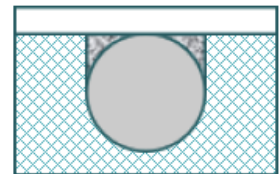

2.

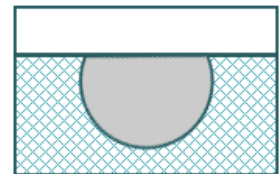

3.

\footnotetext{
${ }^{3}$ Shaaz Ghouse, Sarat Babu, Richard J. Van Arkel, Kenneth Nai, Paul A. Hooper, Jonathan R.T. Jeffers, The influence of laser parameters and scanning strategies on the mechanical properties of a stochastic porous material, Materials \& Design, Volume 131, 2017, Pages 498-508, ISSN 0264-1275, https://doi.org/10.1016/j.matdes.2017.06.041.

${ }^{4}$ Mohammad Shojib Hossain, Jose A. Gonzalez, Ricardo Martinez Hernandez, Mohammad Arif Ishtiaque Shuvo, Jorge Mireles, Ahsan Choudhuri, Yirong Lin, Ryan B. Wicker,Fabrication of smart parts using powder bed fusion additive manufacturing technology, Additive Manufacturing, Volume 10, 2016, Pages 58-66, ISSN 2214-8604, https://doi.org/10.1016/j.addma.2016.01.001.
} 
Figure 3: Options for stop-and-go embedment: 1. Half and Half; 2. U-Shaped Groove; 3. Equal Geometry

The first option, half-and-half design, calls for printing the base of the groove in a semicircular design, inserting the sensor, and then completing the build. The second option is a U-shaped groove that allows the sensor to lie completely below the surface of the base print. The print would continue after embedding. The third option creates a groove of equal cross-sectional area to the sensor. The sensor would then be press fit into the groove, and the print would continue. The first option is precluded by the powder bed rake in the SLM process. Any feature that is superficial to the previously layer will either damage the powder rake or be damaged by it. The third option poses a risk to the sensor; therefore, it also was abandoned. This leaves the second option as the only feasible choice for a stop-and-go embedding process using SLM. Additional manufacturing considerations for embedded sensors include printer contamination from sensor materials and sensor damage from the printing process.

The thermocouple sensor design selected consists of a thin metal sheath with compacted magnesium oxide insulation and two thermocouple wires. Error! Reference source not found, shows a cross-section diagram of the selected thermocouple probes. The design is an ungrounded thermoelement so that it is galvanically isolated from the sheath.

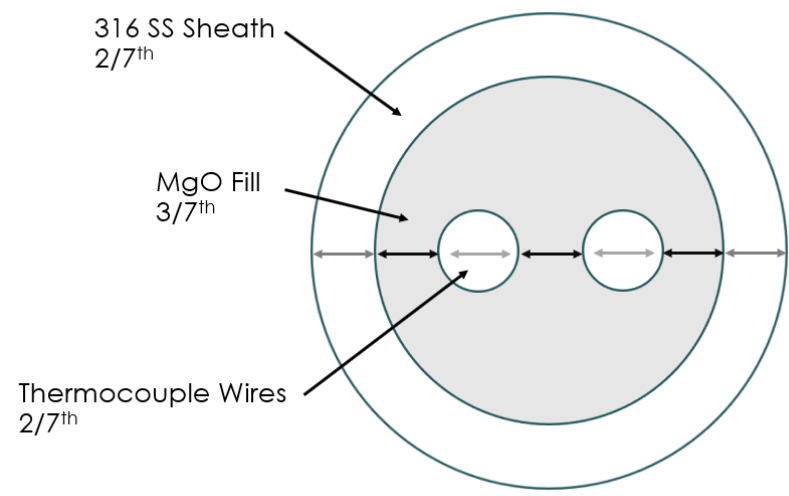

Figure 4: Cross-section of a thermocouple

For a 0.020 in diameter probe, the sheath will have a wall thickness of $0.003 \mathrm{in}$, or $76 \mu \mathrm{m}$. Since the laser penetrates to an average depth of $120 \mu \mathrm{m}$, this raises the risk of melting through the sheath and releasing magnesium oxide powder into the metal powder bed. If this breach were to happen, the powder bed would be contaminated, and the thermocouple itself would be irreparably damaged. The decision was made to embed 316 stainless steel (SS) hypodermic tubing for the first experimental runs of the stop-and-go process to avoid risk of contamination. The actual thermocouple will be inserted into the tubing after completing the build.

Another option to avoid these areas of risk is to simply print a blind geometry into an AM part and insert the sensor afterwards. This, however, carries some additional engineering challenges. Firstly, cleaning metal powder out of a straight printed hole is difficult; cleaning out a blind complex geometry is even more difficult. The possibility of printing an electrode into the parts and removing it after printing was investigate but ultimately deemed to be outside the scope of this project. Also, the option of a complex geometry open at both ends was explored. Cleaning out the excess metal powder would be feasible, but the surface roughness of the SLM part precluded the insertion of the sensor after the print. This surface roughness is also further characterized in later sections. 


\subsubsection{Sensor routing geometry}

Routing of the sensor when using an SLM AM process is most easily accomplished within a plane parallel to the powder bed. Figure 5 illustrates a simplified depiction of a powder bed system. The sequence of manufacture for such systems is to 1) use a roller or rake to produce a uniform surface of the powder bed, 2) deposit laser energy at precise locations to melt and solidify the powder, 3) lower the part, 4) add powder, and repeat from step 1. It is possible to create arbitrary shaped grooves in the part using this method within the resolution of the deposition process. Insertion of an embedded part in the process requires that no surface protrude above the powder bed because it interferes with the raking process that levels the powder bed. Only special three-dimensional shapes can therefore be fabricated using this method.

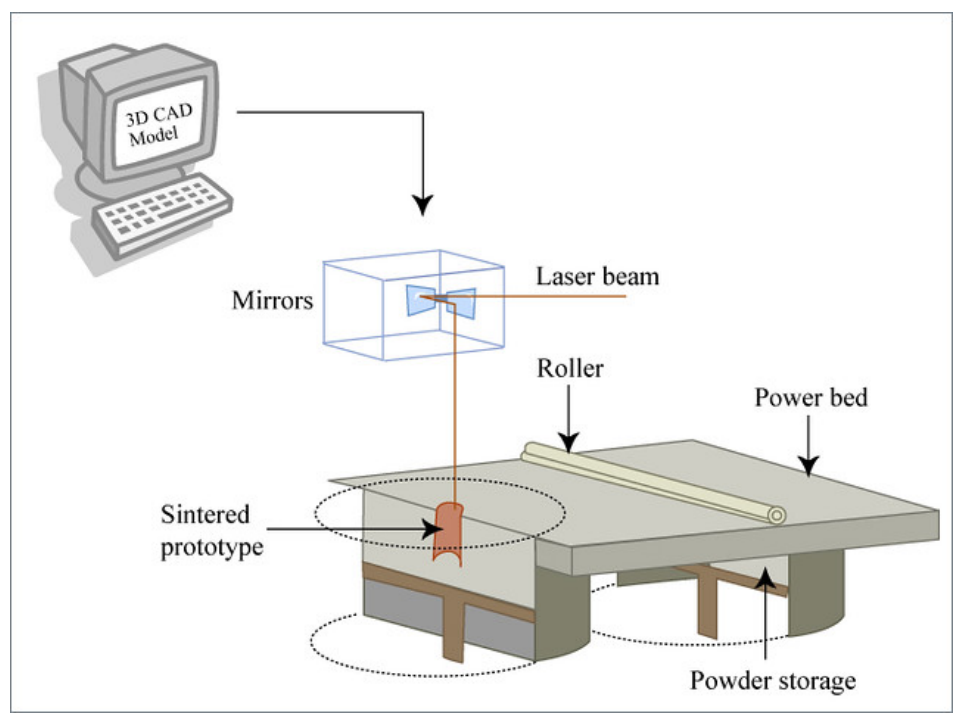

Figure 5 Simplified powder bed additive manufacturing setup

In order to embed sensors with three-dimensional routing paths in structures using this method, the out-of-plane path must be completely defined and available for insertion prior to the build of the in-plane routing path. Figure 6 shows one such configuration. This additional complexity was not explored at this point in the project. Future effort will explore three-dimensional routing paths including the use of less geometrically constrained methods such as DED.

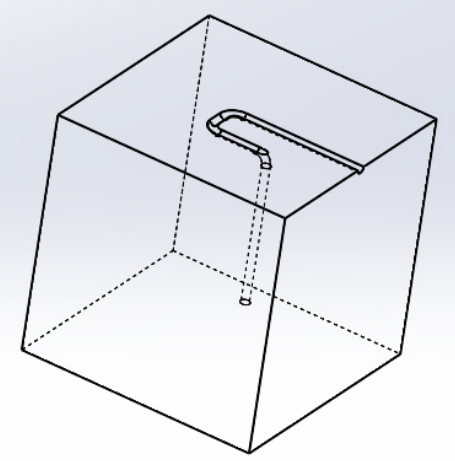


Figure 6 Representation of simplest three-dimensional routing path with one plane of two-dimensional complexity

\subsection{CONCEPTUAL DESIGN OF EMBEDDED SENSOR}

The first phase of embedded sensor design addressed 1) characterizing the SLM process with respect to dimensional accuracy and surface roughness and 2) understanding the stop-and-go embedding process. To address the first subject, a parametric study was designed to quantitatively investigate the influence of the following three features on the final build geometry:

- Embedded groove depth

- Groove width

- Void profile created by the laser source

Figure 7 shows the initial conceptual design with features placed in the part representing these three facets (subdivided into groups of three). For groove depth and width studies, the strategy is to vary one parameter while holding the other constant. Analysis of printing results will help determine the ideal distance and backfill for embedding a sensor. The base plate was conventionally machined to control the depth and width for the first test. Conventional machining provides a low dimensional tolerance uncertainty.

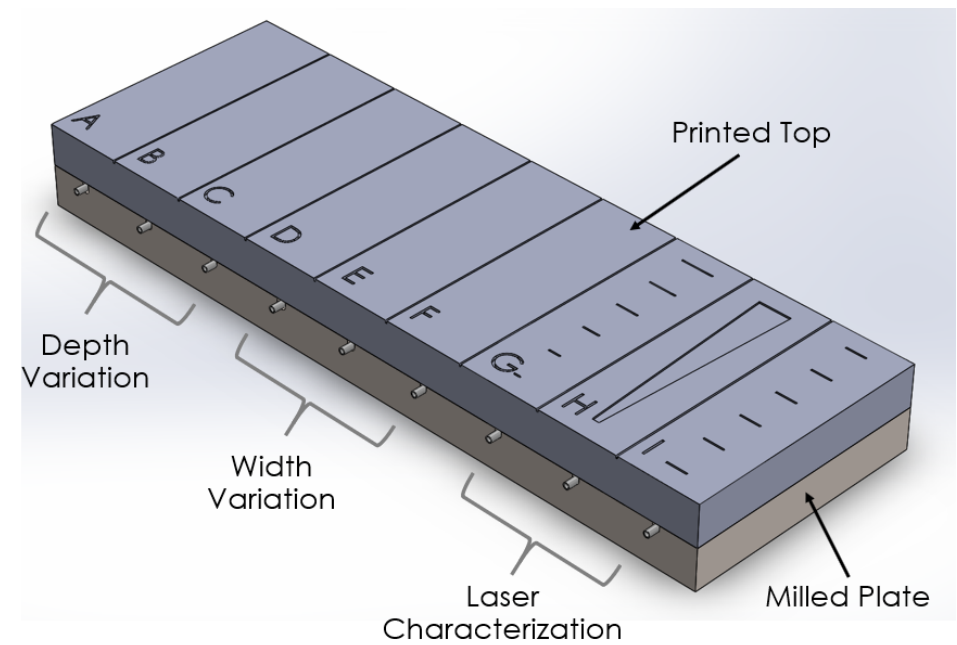

Figure 7: Conceptual design combining conventionally machined part and AM characterization studies

The studies were broken down as seen in Figure 8 for laser characterization. The laser parametric studies focus on both planar accuracy of dimension (e.g., angular variation of voids), and depth of laser penetration (increasing void height). After completing the build, the quality of embedment will be determined by CT scanning each individual section of the part and comparing the results to the reference dimensions in the CAD model. The results of this design will be discussed later. 


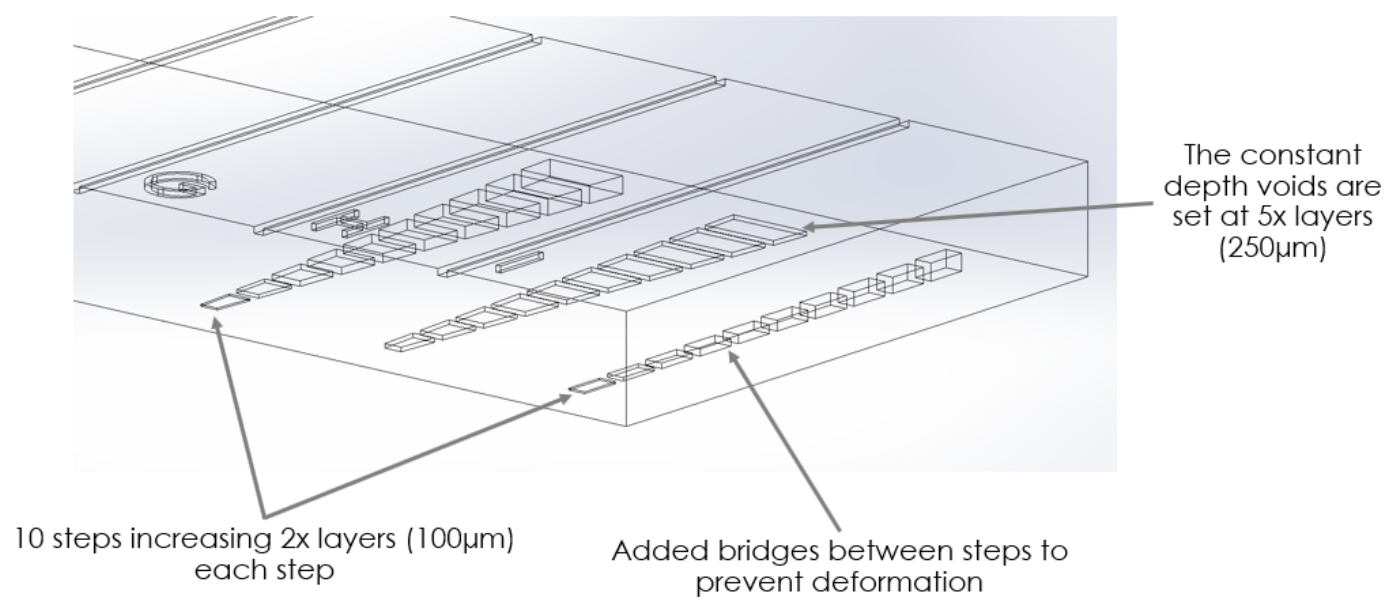

Figure 8: Parametric study of the laser profile

The next phase of conceptual design was to create several parts without any embedded features. These parts would serve as a reference to establish groove dimensions (previously done by conventional machining). These parts would also serve as test subjects for optical profilometry. Two parts were designed with grooves linearly increasing from 0.25 to $2.25 \mathrm{~mm}$ width and depth. These parts are illustrated in Figure 9 .

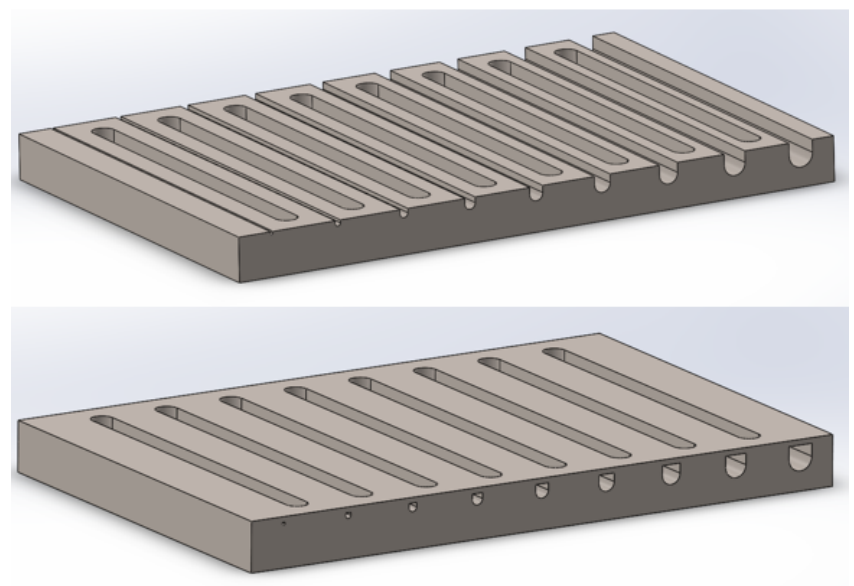

Figure 9: Printed parts for groove dimensional analysis and surface roughness study

In the final phase, a representative geometry for a section of nuclear reactor core was considered. A part was designed that permitted embedment of a sensor using a hexagonal "honeycomb" geometry representative of a TCR core. To this point, straight profile grooves had been printed with embedding following that profile with open ends. However, for the final phase, a blind-end complex geometry was used for the stop-and-go printing process. A complex open channel for embedment post-manufacturing was added as well. This conceptual design is illustrated in Figure 10. 


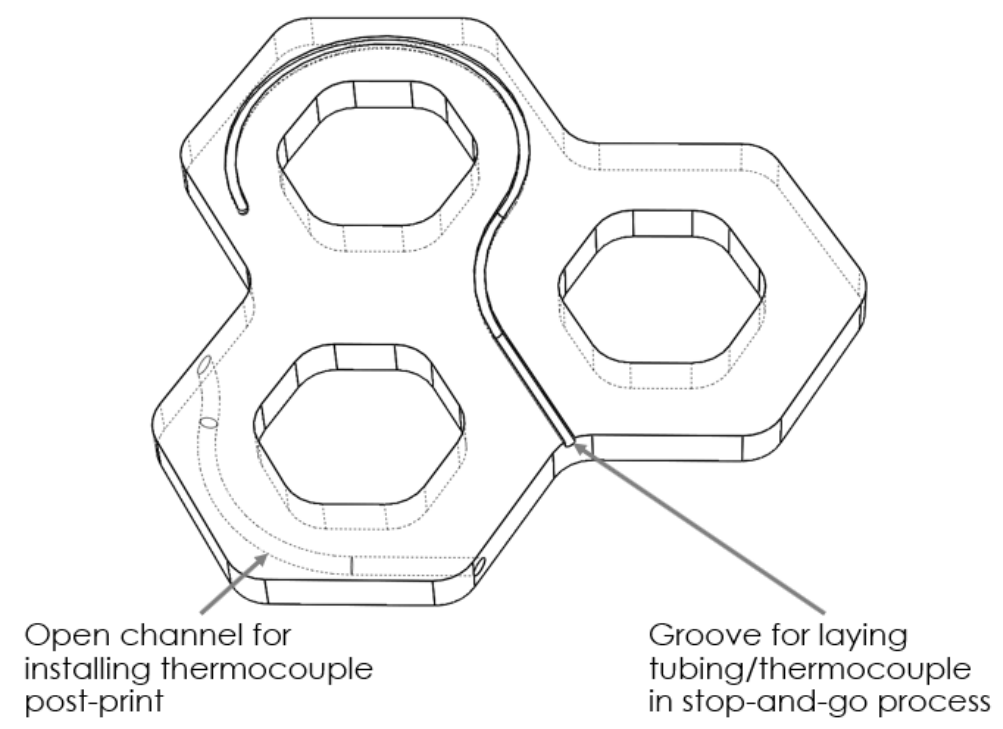

Figure 10: Hexagonal conceptual design

\subsection{PRELIMINARY PROTOTYPING RESULTS}

Following the conceptual design sequence, the first set of results came from conventionally machined parts. Several different machining processes were explored including electrical discharge machining (EDM) and computer numeric control (CNC) mill. Examples of fabricated parts can be seen below in Figure 11.

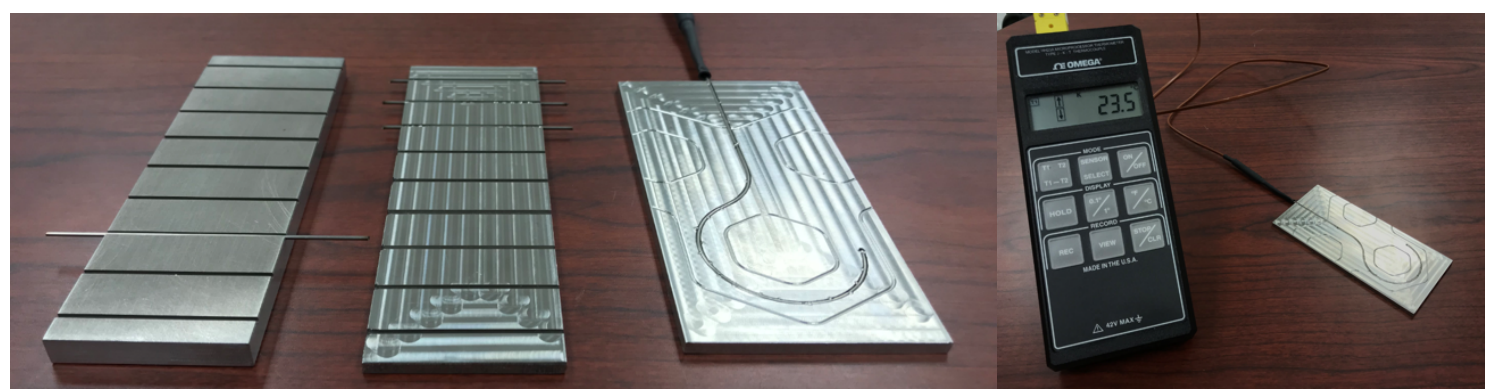

Figure 11: Conventionally machined plates. From left to right - EDM, CNC milling, and CNC milling with embedded thermocouple. Far right shows this thermocouple reading temperature.

The conventionally machined parts were embedded with an $\sim 1 \mathrm{~mm}$ diameter, 316 stainless steel hypodermic tubing. The fit of the tubing was compared on the straight, open groove parts. For the meandering groove on the hexagonal honeycomb design, a representative groove was milled into a SS plate to validate 1) ability to bend and embed the hypodermic tubing into the groove and 2) feasibility of inserting a thermocouple into the tubing after embedment. Both aspects were verified, and the thermocouple was shown to function normally after embedment (also shown in the figure).

The next prototypes fabricated were the parts without any embedded sensors. These parts were fabricated to determine fit of the hypodermic tubing into printed, as opposed to machined, grooves and to investigate the surface roughness of the printed parts. One such part is shown below in Figure 12. 


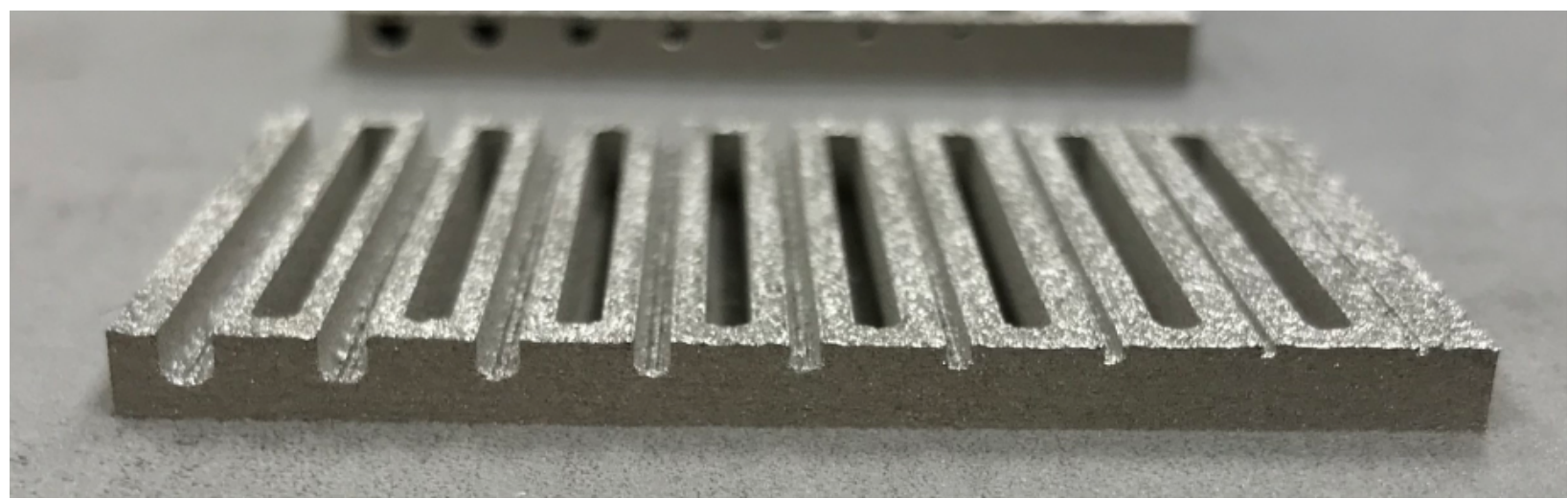

Figure 12: Preliminary printed part with groove depth and width variation ranging from $2.25 \mathrm{~mm}$ (left) to $0.250 \mathrm{~mm}$ (right).

Groove width, as measured at several points using a digital caliper, was shown to be about $100 \mu \mathrm{m}$ smaller than their reference dimension. Using this under-sizing factor, a correction was made such that a $1.25 \mathrm{~mm}$ wide groove was considered appropriate size for the $\sim 1 \mathrm{~mm}$ diameter hypodermic tubing. This groove width was used successfully in succeeding builds of the hexagonal parts.

A Keyence optical profilometer was used to examine surface roughness. Eight total lines were studied across the parts. The averaged results are shown below in Figure 13 with highlighting showing line location.
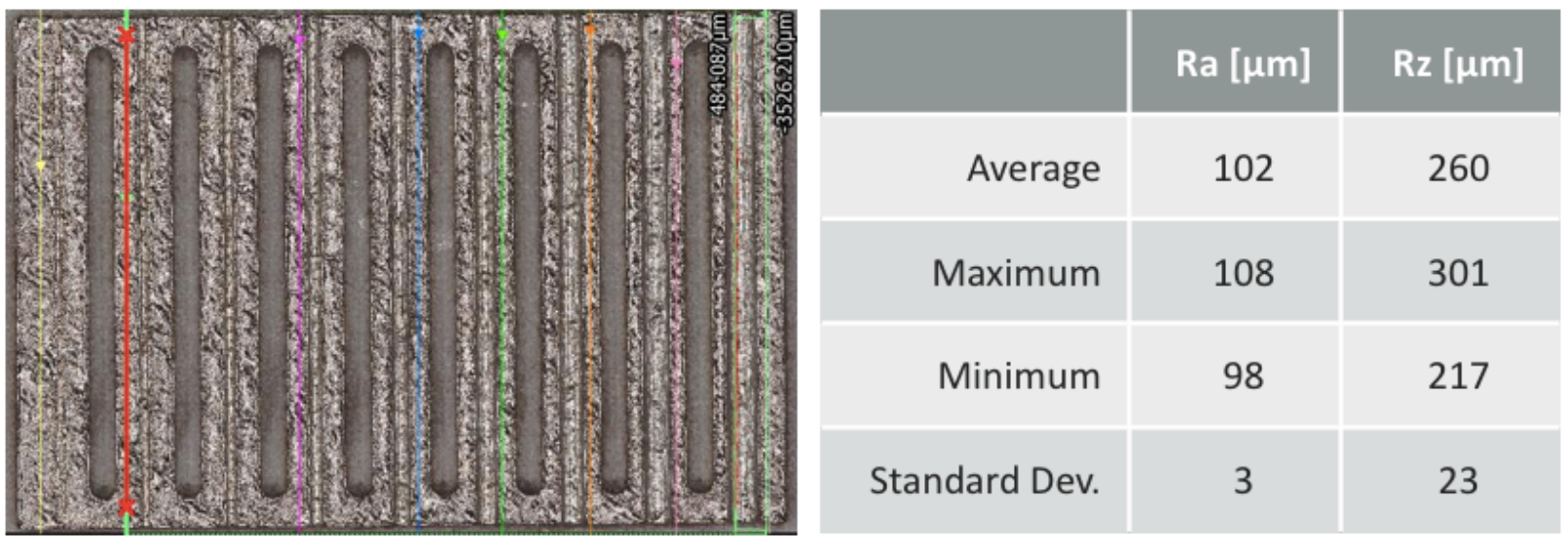

Figure 13: Left shows 8 highlighted lines that were examined by a Keyence optical profilometer. Right shows the results of this study.

The $\mathrm{Ra}$ value for surface roughness is the arithmetical mean of the roughness profile calculated from deviations about the center line. The Rz value is the average distance between the highest peak of the surface and the lowest valley. For the SLM AM parts, the average Ra value is $102 \mu \mathrm{m}$. In terms of comparison, sand casting provides the most similar roughness values with Ra values of up to $50 \mu \mathrm{m}$. Other conventional machining methods such as turning and milling routinely produce Ra values in the range of 1-5 $\mu \mathrm{m}$.

A method of securing the hypodermic tubing in the groove was required. Welding was the best choice given that both the tubing, conventionally machined parts, and AM parts were fabricated from stainless steel. A miniature plasma arc welding tip was employed. The arc, created using argon gas focused around the sharp electrode, resulted in local heating of the joint between the tubing and the base part, melting both metals and forming a coalescent bond. An example weld is shown under a microscope in Figure 14. 


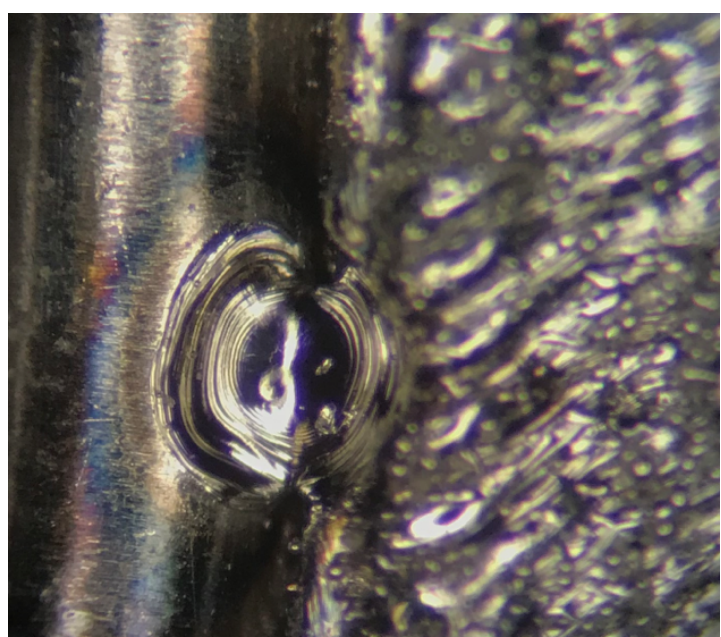

Figure 14: An example of a plasma weld between 316 SS hypodermic tubing and a printed part. Weld settings are: $2 \mathrm{~W} \cdot \mathrm{s}$ power, $2.5 \mathrm{~ms}$ pulse width, sloped waveform, standard tip mode, and nano range (diameter)

This aspect of sensor embedment is particularly important because it is required to mitigate warpage of the sensor. The first attempt to fabricate the parametric study geometry shown in Figure 8 failed because the block with embedded thermocouple sheaths was not adequately secured to the build plate (it rested in a bounding structure without attachment to the build plate). The high thermal gradients through the height of the part produced severe warpage, as shown in Figure 15 below, which interfered with the powder bed raking process prompting termination of the build. Had the block been secured to the build plate, this warpage could have been restrained. Similarly, unsecured sections of the sensor are also subject to large thermal gradients and warpage. Careful attention must therefore be paid to the spacing of attachment points between sensor and primary structure. Future efforts will use analytical approaches or finite element analysis to estimate the magnitude of deformation expected during fabrication due to thermal gradients and specify sensor attachment intervals that maintain out of plane deformation to acceptable limits. At the time of writing of this report, the sample shown in Figure 15 is being prepared for X-ray CT to evaluate the partially completed build.

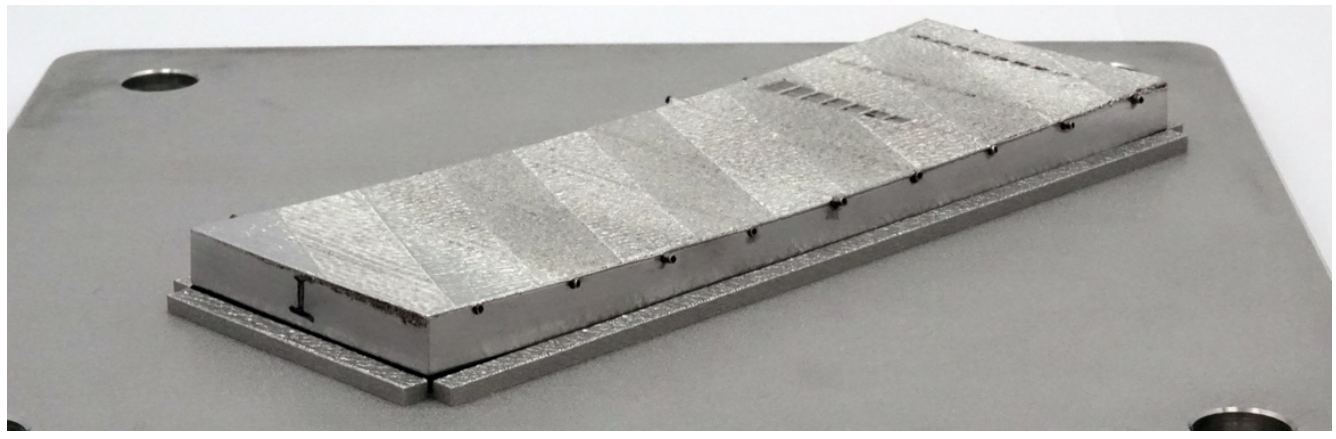

Figure 15: Failed build of machined plate with embedded tubing fabricated using the SLM printer 
In the interest of producing prototype embedded sensors by the end of the first period of performance of the project, the first representative design geometry shown in Figure 10 was fabricated immediately after the failed build of the parametric study block. Figure 16 shows the honeycomb part before embedding, with the thermocouple sheath installed and the completed build. This build was generally considered to be successful, but quantification of the final build geometry and validation of embedded sensor operational integrity will be carried out as described in the following section. It is noted that for this prototype, the build plate was removed from the AM machine in order to spot weld the sheath to the build, followed by reinstallation in the AM machine. A slight offset is evident between the top and bottom pieces of the bed. This occurred because the fit between the bolts securing the build plate to the additive machine is loose, permitting a slight variation in location when the build plate is installed. Future effort will have to either devise a method for precisely locating the build plate within the AM machine, if the build plate is removed, or developing methods for securing the sensor to the build plate without removal from the AM machine.
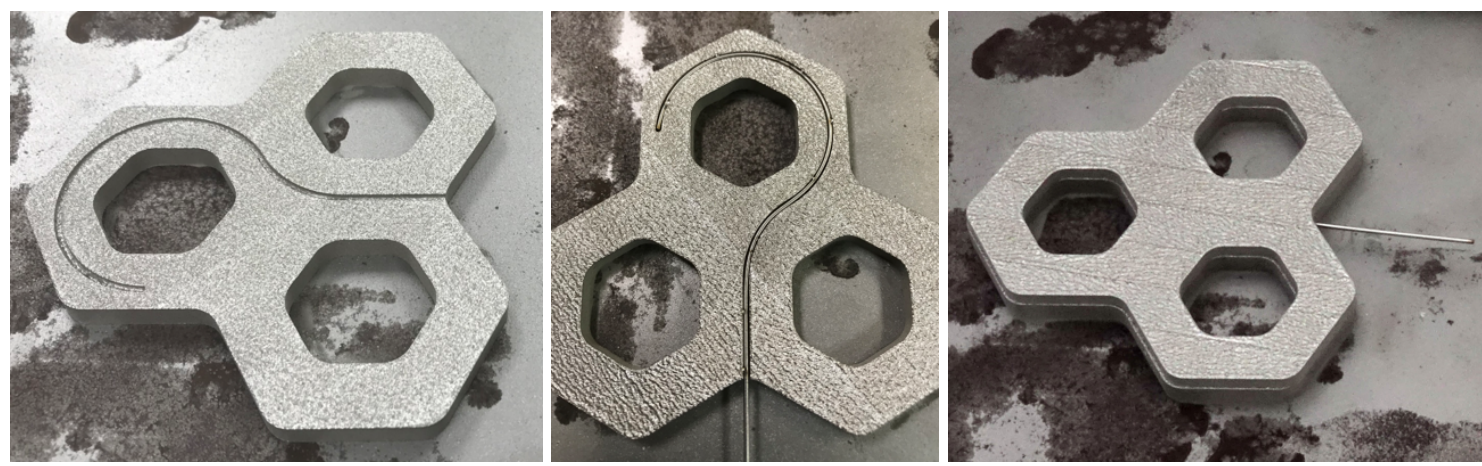

Figure 16: Honeycomb part before embedding, after embedding and completed build

\subsection{EMBEDDED SENSOR TEST PLAN AND FUTURE WORK}

It is noted that the original work plan for this project included a task for structural and operational characterization of fabricated prototypes. Structural evaluation of the build quality and sensor integrity were to be performed using X-ray computed tomography (CT) to quantify as-built dimensions. It was anticipated that if image resolution on the order of 10 microns or less could be achieved, this would be adequate for quantifying the extent of the melt pool and material solidification for the parametric builds, for which the wall thickness of the thermocouple sheath is 76 microns. This understanding is critical to optimizing beam intensity, spot size, and placement to produce the desired build geometry. This method could also be used to determine if the thermocouple sheath had been breached or deformed during the AM process to define build parameters that mitigate sensor damage. Cross sectioning of the part for scanning electron microscopy was also planned if X-ray CT revealed the possibility of unintended material mixing or unfavorable microstructure. Structural characterization of prototypes was not performed prior to the writing of this report because of delays in access to AM equipment, but will be performed as soon as possible. Additionally, high temperature thermal cycling of prototypes was planned in an oven environment but has not yet been performed. The current thermal cycling test plan will rapidly cycle the embedded sensor while taking temperature data, at the maximum ramp rate of the oven, up to a temperature of $600{ }^{\circ} \mathrm{C}$, and back down to room temperature for 25 cycles. Post testing X-ray CT will be performed to determine if part deformation occurs in addition to monitoring sensor performance during the test. These tests will be performed following initial part characterization. 
Phase two tasks for the project will build on the proof-of-concept demonstrated at the end of FY19 by refining fabrication methodologies and adding measurement modalities for embedded commercial off-theshelf (COTS) sensors in the reactor core using advanced manufacturing methods. The tasks will focus on the following three elements:

1) Adding embedded sensing modalities. Year one activities demonstrated the feasibility of embedding COTS thermocouples with ceramic insulation and stainless steel protective sheaths. This element will review available and relevant COTS sensing components, such as self-powered neutron detectors, and develop methodologies for embedding at least one novel sensing modality.

2) Developing a manufacturing approach for embedding COTS sensors with dissimilar materials directly in contact with AM powder materials (e.g. Mo or Nb sheaths). Year 1 demonstrations utilized stainless steel thermocouple sheaths with the same material compositions as the AM powders).

3) Developing methods for emplacing sensors with three-dimensional routing in the AM part. This element addresses the challenge of mechanical interference of the emplaced sensor with the powder bed raking process.

\section{SUMMARY AND CONCLUSIONS}

This report discusses work performed during FY2019 to develop robust and reliable methods for embedding commercial off-the-shelf sensors in metal structures using additive manufacturing (AM) for the transformational challenge reactor (TCR). Embedded sensors are minimally intrusive compared to conventional instrumentation installations and can be placed at physically significant locations in the core. Therefore, embedded sensors hold great potential for increasing the visibility of conditions within the reactor core. This real-time sensory information can be used to improve control of the reactor during operation and potentially better understand thermal and structural loading experienced during operation. Such information is also necessary to confirm design and modeling parameters.

AM was selected as a preferred manufacturing method for this project because it can produce complex twodimensional and three-dimensional routing paths for embedded sensors in manufactured parts. This ability is especially relevant for the complex core design geometry of the TCR. Many fabrication configurations that are possible with AM cannot be realized using conventional manufacturing processes. Another benefit of AM is the ability to create twisting and labyrinthine passages for sensors without fabricating the part in sections and thereby compromising integrity. In contrast, conventional manufacturing approaches often require joining operations to produce such internal features, creating weak interfaces within the part.

Embedment of sensors for metal AM is currently at an early phase of research and development. The approach adopted for this work was to systematically investigate the requirements for sensor embedment, embedment design considerations, sensor placement workflow and methods, and control of the AM process to achieve desired as-built dimensions without compromising the structural integrity of the part or sensor performance. A process workflow was successfully developed and prototype embedded sensor configurations were successfully fabricated. The printing and embedment of a curved thermocouple was demonstrated. Results to date have revealed information on several factors such as the limiting laser energies necessary to prevent melting of the thermocouple sheath and the dimensional uncertainties encountered during the printing process. This early work has identified specific topics for investigation in the next project phase such as adding embedded sensing modalities, interaction of differing materials, and fabrication of three-dimensional sensor channels. Further work will also lead to experimentation with embedding nuclear detectors such as SPNDs. The FY2019 work has been successful in demonstrating that embedding sensors during additive fabrication is feasible. 